\title{
Microphysical sensitivity of coupled springtime Arctic stratocumulus to modelled primary ice over the ice pack, marginal ice, and ocean
}

\author{
Gillian Young, Paul J. Connolly, Hazel M. Jones, and Thomas W. Choularton \\ Centre for Atmospheric Science, School of Earth and Environmental Sciences, University of Manchester, Manchester, UK \\ Correspondence to: Gillian Young (gillian.young@manchester.ac.uk) \\ and Thomas W. Choularton (choularton@manchester.ac.uk)
}

Received: 7 October 2016 - Discussion started: 17 October 2016

Revised: 14 February 2017 - Accepted: 6 March 2017 - Published: 29 March 2017

\begin{abstract}
This study uses large eddy simulations to test the sensitivity of single-layer mixed-phase stratocumulus to primary ice number concentrations in the European Arctic. Observations from the Aerosol-Cloud Coupling and Climate Interactions in the Arctic (ACCACIA) campaign are considered for comparison with cloud microphysics modelled using the Large Eddy Model (LEM, UK Met. Office). We find that cloud structure is very sensitive to ice number concentrations, $N_{\text {ice }}$, and small increases can cause persisting mixedphase clouds to glaciate and break up.

Three key dependencies on $N_{\text {ice }}$ are identified from sensitivity simulations and comparisons with observations made over the sea ice pack, marginal ice zone (MIZ), and ocean. Over sea ice, we find deposition-condensation ice formation rates are overestimated, leading to cloud glaciation. When ice formation is limited to water-saturated conditions, we find microphysics comparable to aircraft observations over all surfaces considered. We show that warm supercooled $\left(-13{ }^{\circ} \mathrm{C}\right)$ mixed-phase clouds over the MIZ are simulated to reasonable accuracy when using both the DeMott et al. (2010) and Cooper (1986) primary ice nucleation parameterisations. Over the ocean, we find a strong sensitivity of Arctic stratus to $N_{\text {ice }}$. The Cooper (1986) parameterisation performs poorly at the lower ambient temperatures, leading to a comparatively higher $N_{\text {ice }}\left(2.43 \mathrm{~L}^{-1}\right.$ at the cloud-top temperature, approximately $-20^{\circ} \mathrm{C}$ ) and cloud glaciation. A small decrease in the predicted $N_{\text {ice }}\left(2.07 \mathrm{~L}^{-1}\right.$ at $\left.-20^{\circ} \mathrm{C}\right)$, using the DeMott et al. (2010) parameterisation, causes mixedphase conditions to persist for $24 \mathrm{~h}$ over the ocean. How-
\end{abstract}

ever, this representation leads to the formation of convective structures which reduce the cloud liquid water through snow precipitation, promoting cloud break-up through a depleted liquid phase. Decreasing the $N_{\text {ice }}$ further $\left(0.54 \mathrm{~L}^{-1}\right.$, using a relationship derived from ACCACIA observations) allows mixed-phase conditions to be maintained for at least $24 \mathrm{~h}$ with more stability in the liquid and ice water paths. Sensitivity to $N_{\text {ice }}$ is also evident at low number concentrations, where $0.1 \times N_{\text {ice }}$ predicted by the DeMott et al. (2010) parameterisation results in the formation of rainbands within the model; rainbands which also act to deplete the liquid water in the cloud and promote break-up.

\section{Introduction}

The significant uncertainties associated with global climate model (GCM) predictions may be largely attributed to the inadequate treatment of sub-grid-scale (such as cloud microphysical) parameterisations (Boucher et al., 2013). These uncertainties are predicted to enhance discrepancies in temperature forecasts at the polar regions of our planet (ACIA, 2005; Serreze and Barry, 2011; Stocker et al., 2013). The accuracy of these forecasts can be improved by developing the modelled representation of the physical processes involved through comparisons with in situ observations (Curry et al., 1996).

Various observational studies have shown that single-layer mixed-phase stratocumulus (MPS) clouds are common in the 
Arctic (e.g. Pinto, 1998; Shupe et al., 2006; Verlinde et al., 2007; Morrison et al., 2012). These clouds have been observed to persist for $\sim 12 \mathrm{~h}$ (Shupe et al., 2006) - with some persisting longer than $100 \mathrm{~h}$ (Shupe et al., 2011) - whilst maintaining cloud-top temperatures as low as $-30^{\circ} \mathrm{C}$ (Verlinde et al., 2007). Single-layer Arctic MPS typically form at low altitudes and maintain a liquid layer at cloud top which facilitates ice formation and precipitation below (Rangno and Hobbs, 2001; Shupe et al., 2006; Verlinde et al., 2007; McFarquhar et al., 2011; Jackson et al., 2012; Morrison et al., 2012, amongst others). The Wegener-Bergeron-Findeisen (WBF) mechanism strongly influences MPS and initiates a continually changing microphysical structure. Moderate vertical motions maintain these clouds, where mixing ensures that the proximity between ice crystals and cloud droplets is variable whilst sustaining supersaturated conditions (Korolev and Isaac, 2003).

Models do not reproduce the microphysical structure and radiative interactions of these persistent Arctic mixed-phase clouds well (e.g. Tjernström et al., 2008; Klein et al., 2009; Morrison et al., 2009, 2012; de Boer et al., 2014). Detailed cloud resolving model (CRM) simulations have previously shown that commonly used midlatitude parameterisations for primary ice formation, such as Cooper (1986) or Meyers et al. (1992), overestimate the cloud ice number concentration, $N_{\text {ice, }}$, in Arctic MPS, causing the rapid depletion of liquid and cloud glaciation (Harrington et al., 1999; Prenni et al., 2007). Modelled MPS are particularly sensitive to $N_{\text {ice }}$, with small decreases in simulated ice number causing significant increases in modelled liquid water path (Harrington and Olsson, 2001).

Ice crystals may form through primary or secondary processes in Arctic MPS (Rangno and Hobbs, 2001). Here, we focus on primary ice formation as secondary ice production has been shown to be less influential in the springtime MPS we shall consider (e.g. Jackson et al., 2012; Young et al., 2016a). Primary ice particles may be nucleated heterogeneously through four different modes: deposition, condensation, immersion, and contact (Pruppacher and Klett, 1997). These modes describe the deposition of water vapour onto an ice nucleating particle (INP), forming ice directly (deposition) or freezing upon condensation (condensation), or the freezing of a cloud droplet through activation from within (immersion) or collision with an INP (contact). Due to their similarities, it can be difficult to differentiate between these mechanisms in measurements; for example, deposition or immersion nucleation are often quoted to occur alongside condensation-freezing processes (e.g. Cooper, 1986; Meyers et al., 1992; de Boer et al., 2010; Fan et al., 2016). Three of these mechanisms (immersion-, contact-, and condensationfreezing) require the presence of cloud droplets for initiation (Pruppacher and Klett, 1997), whereas deposition nucleation may occur in ice-supersaturated conditions.

The frequency of MPS in the Arctic suggests that ice formation in these clouds is tied to the liquid phase, as prefer- ential nucleation via the deposition mode may, in theory, result in a higher proportion of fully glaciated clouds than are observed (de Boer et al., 2011; Vihma et al., 2014). Consequently, recent studies (e.g. de Boer et al., 2011) suggest that liquid-dependent modes of nucleation are dominant in Arctic MPS at subzero temperatures greater than $-25^{\circ} \mathrm{C}$. Liquiddependent freezing may be inferred by observations in the Arctic, as previous studies have found correlations between the number concentrations of ice crystals and large $(>23 \mu \mathrm{m})$ cloud drops (and drizzle drops; Hobbs and Rangno, 1998; Rangno and Hobbs, 2001). These large liquid particles have an increased likelihood of containing a partially insoluble nucleus or colliding with one due to aerosol scavenging; therefore, they may nucleate via the immersion- or contactfreezing modes respectively. Arctic aerosol particles are often well-mixed due to long-range transport (Young et al., 2016b); therefore, they may provide an efficient platform for immersion-freezing (Bigg and Leck, 2001; de Boer et al., 2010). Similarly, mixed particles can promote ice nucleation through collisions with cloud droplets; however, contactfreezing nuclei are generally thought to be predominantly insoluble and ice active, with little ability to act as a cloud condensation nuclei (CCN; Young, 1974).

Investigating the sensitivity of springtime Arctic MPS to ice crystal number concentrations will help to improve our understanding of the microphysical limitations of these clouds. Here, we test whether primary ice formation under water-saturated conditions improves the modelled microphysical structure in comparison to the commonly used deposition conditions (below water saturation). We do not specify a nucleation mode: simply, ice formation can only occur when liquid cloud droplets are present, producing a number concentration specified by the chosen parameterisation. We hypothesise that ice number concentrations will be suppressed and liquid fractions will be enhanced under this restriction, thus reducing the influence of the WBF mechanism and prolonging cloud lifetime. Modelling studies which specifically utilise immersion-freezing have successfully simulated the persistence of Arctic stratocumulus clouds, producing sustained liquid water in the presence of ice crystals for up to $12 \mathrm{~h}$ (de Boer et al., 2010).

Here, we use in situ cloud observations of Arctic MPS, from the Aerosol-Cloud Coupling and Climate Interactions in the Arctic (ACCACIA) campaign of 2013, for guidance to infer the microphysical sensitivity of modelled clouds to both ice number and surface conditions. We use the Large Eddy Model (LEM, UK Met Office, Gray et al., 2001) to simulate cloud microphysics observed over the sea ice, marginal ice zone (MIZ), and ocean. The UK's BAe-146-301 Atmospheric Research Aircraft was used during the springtime (March-April) campaign, collecting high-resolution in situ observations of the cloud microphysics encountered (Lloyd et al., 2015; Young et al., 2016a). Several dropsondes were launched from the aircraft during these cases to provide vertical profiles of the boundary layer (BL) structure. By com- 
bining dropsonde and in situ measurements, the sensitivity of modelled cloud microphysics to changes in predicted ice number concentrations is tested to infer the microphysical limitations of persistent springtime MPS in the European Arctic.

\section{Methodology}

\subsection{Aircraft instrumentation}

Measurements from instruments on board the Facility for Airborne Atmospheric Measurements' (FAAM) BAe-146 aircraft during three chosen case studies are presented to test the ability of the LEM to reproduce the Arctic mixedphase clouds observed. Specifically, data from two wingmounted instruments - the 2-Dimensional Stereo Particle imaging probe (2DS, Lawson et al., 2006) and Cloud Droplet Probe (CDP-100 Version 2, Droplet Measurement Technologies (DMT), Lance et al., 2010) - are used to investigate the mixed-phase clouds, as these probes can measure the sizes and number concentrations of ice crystals $(80-1280 \mu \mathrm{m})$ and cloud droplets $(3-50 \mu \mathrm{m})$ respectively. Details on the functioning of these probes, data analysis, and subsequent particle phase discrimination have been discussed previously by Crosier et al. $(2011,2014)$ and Taylor et al. (2016). The use of these instruments during ACCACIA is discussed by Lloyd et al. (2015) and Young et al. (2016a).

Data from the Passive-Cavity Aerosol Spectrometer Probe (PCASP 100-X, Droplet Measurement Technologies, Rosenberg et al., 2012) are used to size and count aerosol particles from sizes 0.1 to $3 \mu \mathrm{m}$. Aerosol particle data are used for the evaluation of the DeMott et al. (2010) ice nucleation parameterisation. Additionally, dropsondes released during each case are used to provide representative vertical profiles of potential temperature, water vapour mixing ratio, and wind fields to initialise the model.

\subsection{Large Eddy Model (LEM)}

The LEM allows cloud microphysics to be studied in isolation from large-scale meteorological features. Cloud microphysical interactions, wind velocities, and turbulent motions within the boundary layer are simulated to allow a detailed investigation of cloud formation and evolution over a 3-D domain (Boucher et al., 2013). Here, we consider three case studies of observations over the sea ice, marginal ice zone (MIZ), and ocean: cases 1, 2, and 3 respectively.

A $16 \mathrm{~km} \times 16 \mathrm{~km}$ domain was used, centred on the respective dropsonde release points in each case, with a spatial resolution of $120 \mathrm{~m}$ and a model height of $3 \mathrm{~km}$ applied. A vertical resolution of $20 \mathrm{~m}$ was imposed from the surface to above the altitude of the boundary layer temperature inversion $(1500 \mathrm{~m})$, above which it was reduced to $50 \mathrm{~m}$. The LEM was run for $24 \mathrm{~h}$ to simulate the respective observations. The first $3 \mathrm{~h}$ of each simulation were not considered due to model

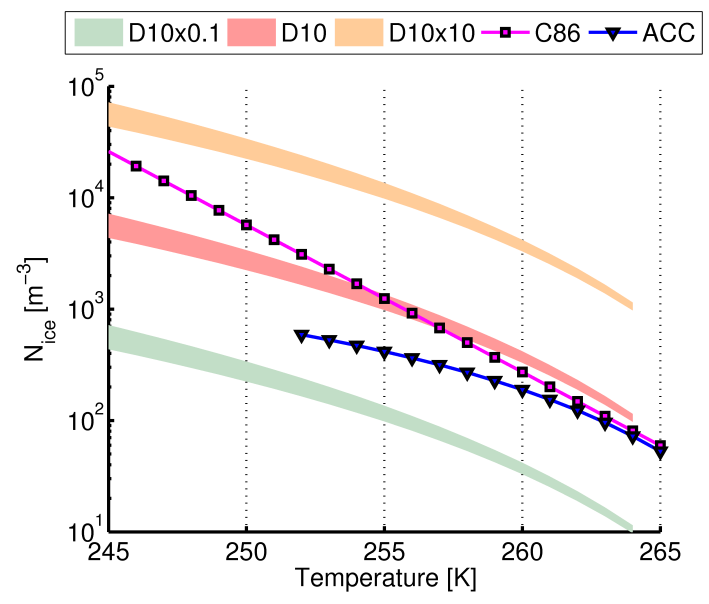

Figure 1. Evaluation of the five parameterisations used (C86, D10, ACC, D $10 \times 0.1$, and D $10 \times 10$ ) in the three cases considered with respect to temperature. The $\mathrm{C} 86$ parameterisation and ACC are valid for all cases, whereas the different aerosol particle loadings, and thus, variability, are accounted for with the D10 parameterisation.

spin-up. For all cases, cyclic lateral boundary conditions were imposed. A sponge layer was applied to the top $500 \mathrm{~m}$ of the domain, allowing the fields to revert back to their initial conditions in this region. Long- and shortwave radiation were modelled using the Edwards and Slingo (1996) scheme and called every $150 \mathrm{~s}$ within the model. Dropsonde profiles of potential temperature, wind speed, and water vapour mixing ratio were used for initialisation. An adiabatic liquid water profile was assumed up to the first temperature inversion (approximately 600, 350, and $1150 \mathrm{~m}$ for cases 1, 2, and 3 respectively).

Over the MIZ and ocean (cases 2 and 3), surface fluxes were calculated by the model, which assumes a water-saturated ocean surface. Small sensible heat fluxes $\left(1 \mathrm{~W} \mathrm{~m}^{-2}\right)$ were imposed to simulate the sea ice surface (case 1 ), as studies have measured such values adjacent to the ice pack (e.g. Sotiropoulou et al., 2014). These surface conditions were kept constant throughout each simulation. A variable time step was imposed to satisfy Courant-FriedrichsLewy (CFL) criteria (Courant et al., 1967), and dt was approximately $0.3,0.4$, and $0.2 \mathrm{~s}$ for cases 1,2 , and 3 , respectively. Sub-Arctic McClattchey profiles of tropospheric temperature, pressure, water vapour, and ozone - based on historic measurements of stratospheric transmittance - were imposed in all simulations to ensure the initialised vertical profiles were representative of the environment modelled.

No large-scale subsidence was imposed in these simulations to allow the microphysical effect of ice number and surface fluxes to be studied in isolation. Imposed subsidence would affect the microphysical structure of the modelled clouds, and the effect of including large-scale subsidence is discussed in Sect. 5.3. 
Table 1. Predicted number concentrations of ice crystals, $N_{\text {ice }}\left[\mathrm{L}^{-1}\right]$, using each parameterisation considered in this study at the observed cloud-top temperatures in each case.

\begin{tabular}{lrrrrrrr}
\hline $\begin{array}{l}\text { Case } \\
\text { number }\end{array}$ & $\begin{array}{r}\text { Temperature }^{\mathrm{a}} \\
{\left[\mathrm{K}\left({ }^{\circ} \mathrm{C}\right)\right]}\end{array}$ & $\mathrm{D}^{\mathrm{b}} 0^{\mathrm{b}} \times 10$ & $\mathrm{C} 86$ & $\mathrm{D} 10^{\mathrm{b}}$ & ACC & $\mathrm{D}^{\circ} 0^{\mathrm{b}} \times 0.1$ \\
\hline 1 & $253.4(-19.8)$ & 13.1 & 2.03 & 1.31 & 0.51 & 0.13 \\
2 & $260.5(-12.7)$ & 3.37 & 0.23 & 0.34 & 0.17 & 0.03 \\
3 & $252.8(-20.4)$ & 20.7 & 2.43 & 2.07 & 0.54 & 0.21 \\
\hline
\end{tabular}

${ }^{\mathrm{a}}$ Cloud-top temperature (CTT). ${ }^{\mathrm{b}} N_{\mathrm{INP}}\left[\mathrm{L}^{-1}\right]$.
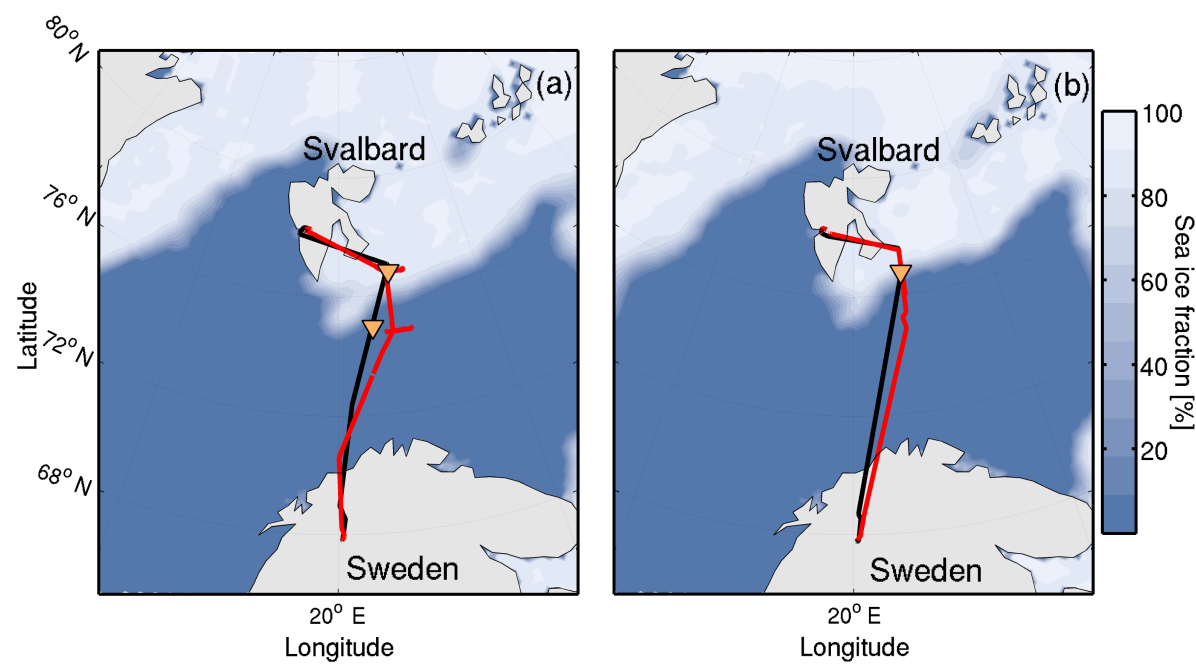

Figure 2. Flight track of (a) B762 and (b) B764, with section 1 (black) and section 2 (red) indicated. Dropsondes were released during section 1, whilst in situ observations were made during section 2. Dropsonde release locations are marked (orange triangles). (a) Case 1 (sea ice, north) and case 3 (ocean, south) are from flight B762, (b) case 2 (MIZ) is from B764. Sea ice fraction is shown in shading.

\subsubsection{Primary ice nucleation}

The Morrison et al. (2005) microphysics scheme is used within the LEM to test the sensitivity of the simulated mixed-phase Arctic clouds to ice number concentration. This scheme represents single-moment liquid, with a prescribed droplet number, and double-moment ice, snow, graupel, and rain. Quoted $N_{\text {isg }}$ in this article represents the summed contributions of the ice crystal, snow, and graupel number concentrations simulated. 2DS measurements are not segregated into such categories; therefore, bulk, "total ice" number concentrations are compared. A prescribed droplet number of $100 \mathrm{~cm}^{-3}$, approximated from the measured values of $110 \pm 36,141 \pm 66$, and $63 \pm 30 \mathrm{~cm}^{-3}$ (Young et al., 2016a) for cases 1,2, and 3 respectively, is applied in all simulations. The sensitivity of the ice phase to this number is not considered here.

Three distinct ice nucleation parameterisations were imposed in this study (Fig. 1). Firstly, the depositioncondensation ice nucleation parameterisation proposed by Cooper (1986) (hereafter, C86) was tested against the ACCACIA observations. This relationship is commonly used within the Morrison microphysics scheme in the Weather Research and Forecasting (WRF) model, amongst others. In Eq. (1), $N_{\text {ice }}$ represents the primary ice number concentration, and $T_{0}-T_{\mathrm{K}}$ defines the subzero temperature. This parameterisation is used to simulate ice number concentrations below $265 \mathrm{~K}$ only.

$N_{\text {ice }}\left(T_{\mathrm{K}}\right)\left[\mathrm{m}^{-3}\right]=5 \cdot \exp \left(0.304\left[T_{0}-T_{\mathrm{K}}\right]\right)$

Secondly, an approximation of the DeMott et al. (2010) (hereafter, D10) parameterisation was applied (Eq. 2). This study derived a detailed relationship between INP number, temperature, and aerosol number concentration based on an amalgamation of different INP field data. D10 was imposed at temperatures below $264 \mathrm{~K}$ and at water saturation (in accordance with DeMott et al., 2010). Equation (2) predicts the number concentration of INPs active at the given temperature (in Kelvin), $T_{\mathrm{K}}$. As input, it requires $n_{\mathrm{aer}, 0.5}$ : the number concentration of aerosol particles with diameter, $D_{\mathrm{P}}$, greater than $0.5 \mu \mathrm{m}$. These aerosol data were averaged using PCASP measurements in the close vicinity to the observed cloud, 
producing input concentrations of $1.13,1.77$, and $2.20 \mathrm{~cm}^{-3}$ over the sea ice, MIZ, and ocean respectively. Below-cloud data were solely used over the ocean, whereas above-cloud measurements were included in the sea ice and MIZ calculations as the observed clouds had sub-adiabatic liquid water profiles, making entrainment processes from the lateral or top boundaries of the clouds likely.

$$
\begin{aligned}
N_{\mathrm{INP}}\left(T_{\mathrm{K}}\right)\left[\mathrm{m}^{-3}\right] & =0.0594\left(273.16-T_{\mathrm{K}}\right)^{3.33} \\
& \left(n_{\mathrm{aer}, 0.5}\right)^{0.0264\left(273.16-T_{\mathrm{K}}\right)+0.0033}
\end{aligned}
$$

Additionally, a curve was fitted to the observed ice crystal number concentrations during the ACCACIA campaign and used within the model (Eq. 3). Data from ACCACIA flights B761, B762, B764, B765, and B768 were included in the derivation of this curve. Microphysical data from B762, and B761/B768, have been previously detailed by Young et al. (2016a) and Lloyd et al. (2015) respectively. Young et al. (2016b) illustrate the corresponding flight tracks of each of these cases. Bulk number concentrations from these flights were plotted against temperature and the following relationship was derived from these data:

$$
N_{\text {ice }}\left(T_{\mathrm{K}}\right)\left[\mathrm{m}^{-3}\right]=\frac{0.068\left(273.5-T_{\mathrm{K}}\right)^{3.3}}{\exp \left(0.05\left(273.16-T_{\mathrm{K}}\right)\right)}
$$

This curve is valid below $265 \mathrm{~K}$. Temperatures greater than this were subject to minor secondary ice production; therefore, the primary ice component could not be cleanly extracted from those data. These observed ice data spanned 252 to $265 \mathrm{~K}$. In this article, this curve will be abbreviated to ACC. We expect this empirically derived relationship to perform well in comparison to the observations; therefore, ACC is used to assess how well the two established parameterisations, C86 and D10, reproduce the cloud microphysics observed.

INPs are not depleted in this study; however, ice crystal number concentrations are prognostic within the Morrison et al. (2005) microphysics scheme. Aerosol particles are not strictly represented in the LEM and the microphysical representation is bulk, not binned. These simulations are only representative of a system with a replenishing source of INPs, and are therefore idealistic representations of the modelled clouds. However, this set-up can give an approximation of the cloud microphysics that may form in the vicinity of an INP source; for example, a local source at the surface or a long-range transported INP population aloft.

The primary objective of this study is to identify the sensitivity of cloud stability to ice crystal number concentration.
DeMott et al. (2010) suggest that INP number concentrations need to be predicted to within a factor of 10 to avoid an unrealistic treatment of mixed-phase cloud microphysics. Therefore, $\mathrm{D} 10 \times 10$ and $\mathrm{D} 10 \times 0.1$ were considered, in addition to C86, D10, and ACC, to additionally test sensitivity of simulated mixed-phase cloud microphysics to large changes in ice crystal number concentration. We chose D10 for this sensitivity study as this is the more up-to-date of the two established parameterisations considered. Figure 1 illustrates the performance of each parameterisation considered: the C86 and ACC cases, dependent only on temperature, are valid across the three observational studies chosen, whilst the D10 parameterisation - and variations thereof - is variable between cases given its dependence on observed aerosol particle number concentrations.

\section{Aircraft observations}

In situ observations of cloud microphysics over the sea ice and ocean during ACCACIA flight B762 (23 March 2013), and over the MIZ during flight B764 (29 March 2013), are considered for model comparison. Microphysical observations from flight B762 have been detailed previously by Young et al. (2016a). The corresponding flight tracks are illustrated in Fig. 2. The case studies were chosen due to the availability of dropsondes for model initialisation and temporally close in situ aircraft observations. These aircraft observations sampled the same geographical location approximately $3-5 \mathrm{~h}$ after the dropsonde measurements; therefore, some evolution in cloud properties between the two data is expected. These dropsonde data were affected by a potential dry bias, as discussed by Young et al. (2016a): corrections were applied after this study was completed, and the revised profiles are shown in Figs. S1 and S2 in the Supplement. Whilst the general properties of the modelled clouds are mostly unchanged with these corrections imposed, the development of precipitation is affected (examples shown in Figs. S4, S5). Our conclusions are unaffected by this bias; however, these revised profiles highlight an additional sensitivity to humidity in the three cases considered here (see the Supplement for further details).

Dropsondes from B762 distinctly sampled either the sea ice or ocean (as shown in Fig. 2a). The ocean dropsonde was far from the sea ice edge $(\sim 140 \mathrm{~km})$. The B764 dropsonde (Fig. 2b) was dropped over the MIZ. As in Young et al. (2016a), the MIZ is defined as sea ice fractions $>10$ and $<90 \%$ based on NSIDC data (National Snow and Ice Data Centre, Fig. 2). These three cases were conducted over similar longitudes $\left(\sim 27^{\circ} \mathrm{E}\right)$ and approximately the same latitude range $\left(\sim 75-77^{\circ} \mathrm{N}\right)$

Figure 3 shows the potential temperature, vapour, and wind speed profiles measured by each dropsonde used to initialise the LEM. In all cases, the net wind direction was north-north-easterly, bringing cold air from over the sea ice 

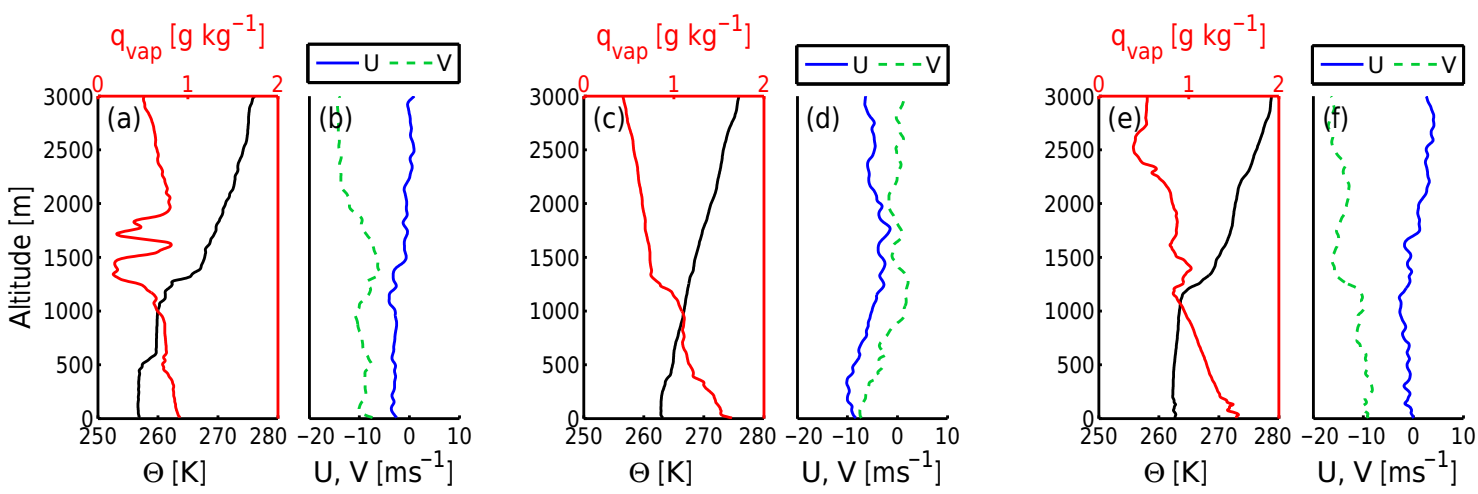

Figure 3. Potential temperature, vapour mixing ratio, and wind speed profiles measured by the three dropsondes used to initialise the LEM in this study. (a-b) Dropsonde 1 released over the sea ice during flight B762. (c-d) Dropsonde 2 released over the MIZ during flight B764. (e-f) Dropsonde 3 released over the ocean during flight B762.

Table 2. Summary of cloud observations for each of the three cases considered. Values quoted are averaged quantities, with $1 \sigma$ in brackets.

\begin{tabular}{llllrrr}
\hline $\begin{array}{l}\text { Case } \\
\text { number }\end{array}$ & Flight & $\begin{array}{l}\text { Date } \\
{[2013]}\end{array}$ & $\begin{array}{l}\text { Surface } \\
\text { conditions }\end{array}$ & $\begin{array}{r}\text { Cloud } \\
\text { extent }[\mathrm{m}]\end{array}$ & $\begin{array}{r}\mathrm{LWMR}^{\mathrm{a}} \\
{\left[\mathrm{g} \mathrm{kg}^{-1}\right]}\end{array}$ & $\begin{array}{r}N_{\text {ice }}^{\mathrm{b}} \\
{\left[\mathrm{L}^{-1}\right]}\end{array}$ \\
\hline 1 & B762 & 23 March & Sea ice & $300-700$ & $0.05(0.04)$ & $0.47(0.86)$ \\
2 & B764 & 29 March & MIZ/Ocean & $200-900$ & $0.09(0.07)$ & $0.35(0.20)$ \\
3 & B762 & 23 March & Ocean & $700-1500$ & $0.24(0.13)$ & $0.55(0.95)$ \\
\hline
\end{tabular}

${ }^{a}$ Liquid water mixing ratio. ${ }^{\mathrm{b}}$ Ice crystal number concentration.
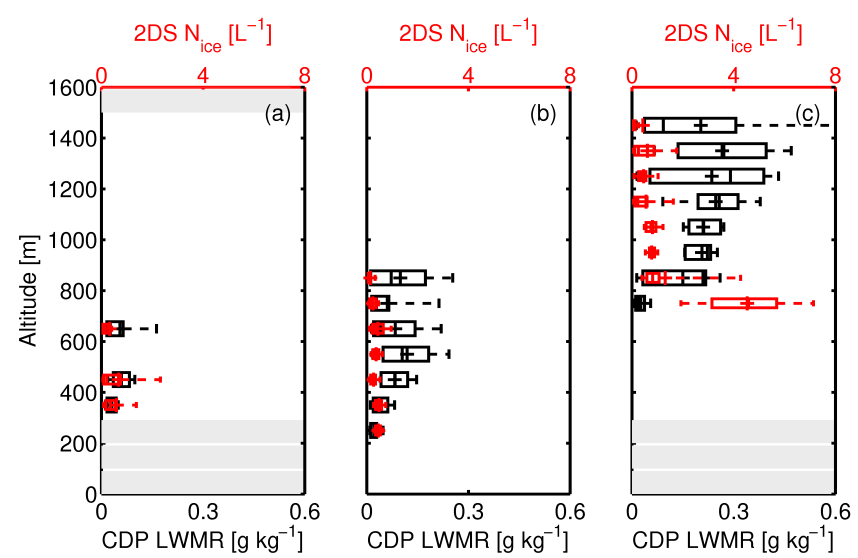

Figure 4. Observations of 2DS ice number concentration (red) and CDP liquid water mixing ratio (LWMR, black). (a) Sea ice, case 1. (b) MIZ, case 2. (c) Ocean, case 3. Only observations from mixedphase clouds are included, with a derived CDP liquid water content threshold of $\geq 0.01 \mathrm{~g} \mathrm{~m}^{-3}$ distinguishing in-cloud measurements. Box edges: 25th and 75th percentiles, Median is 1 , and mean is + . Altitudes not sampled by the aircraft are indicated with grey boxes.

pack to the comparatively warm ocean. The potential temperature profile for the sea ice case (case 1) displays a double inversion; the first at $\sim 500 \mathrm{~m}$ and the second at $\sim 1200 \mathrm{~m}$. The latter inversion is at approximately the same altitude as that measured downstream over the ocean (case 3 ). The MIZ case shows a subtle inversion at approximately $350 \mathrm{~m}$; however, it is not as prominent as the other two cases.

In situ measurements for all cases show a distinct, mixedphase cloud from approximately 300 to $700 \mathrm{~m}$ (case 1), 200 to $900 \mathrm{~m}$ (case 2), and 700 to $1500 \mathrm{~m}$ (case 3, Fig. 4). These measurements are summarised in Table 2. Liquid water mass mixing ratios (LWMRs), derived from CDP measurements, provide a direct comparison with the LEM: the liquid measurements in the sea ice case are low, of the order of $\sim 0.05 \mathrm{~g} \mathrm{~kg}^{-1}$, whereas the MIZ and ocean cases have larger mixing ratios $\left(\sim 0.1-0.2 \mathrm{~g} \mathrm{~kg}^{-1}\right)$. 2DS ice number concentrations are consistently low within the cloud layer in all cases, of the order of approximately $0.2-1.5 \mathrm{~L}^{-1}$. High ice number concentrations at cloud base in case 3 are thought to be minor contributions of secondary ice due to crystal fragmentation (Young et al., 2016a). Cloud-top temperatures (CTTs) were approximately $-20,-13$, and $-20^{\circ} \mathrm{C}$ respectively (Table 1). Such temperatures are too cold for efficient secondary ice production and too warm for homogeneous ice nucleation (Hallett and Mossop, 1974; Pruppacher and Klett, 1997). For this study, modelled microphysics below $1500 \mathrm{~m}$ is focused upon as this is directly comparable with these aircraft observations. 

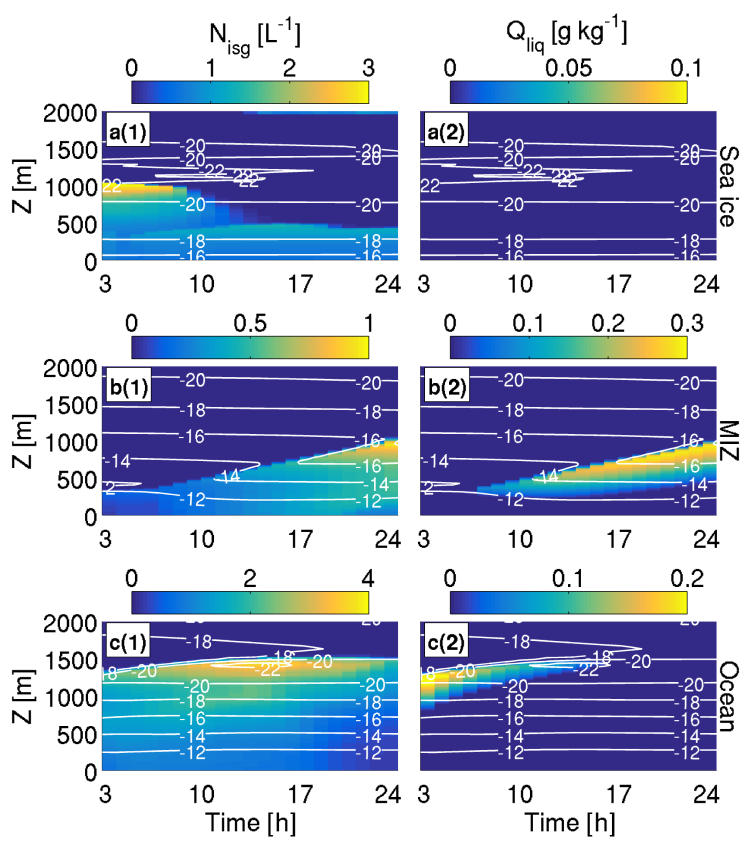

Figure 5. Simulated ice number concentrations $\left(N_{\text {isg }}\right.$, a1-c1 $)$ and liquid water mixing ratios $\left(Q_{\text {liq }}, \mathbf{a} 2-\mathbf{c 2}\right)$ using the C86 parameterisation under default WRF conditions $\left(T<-8^{\circ} \mathrm{C}, S_{\mathrm{W}}>0.999\right.$, or $S_{\mathrm{i}}>1.08$ ). (a) Sea ice (case 1), (b) MIZ (case 2), (c) Ocean (case 3). Run length $24 \mathrm{~h}$. Temperature $\left({ }^{\circ} \mathrm{C}\right)$ contours are overlaid in white. Note changing colour bar for each subfigure.

\section{Results}

\subsection{Control simulations}

Within the Morrison et al. (2005) bulk microphysics scheme, primary ice nucleation is represented by three separate parameterisations: one each for deposition-condensation, immersion (Bigg, 1953), and contact (Meyers et al., 1992) nucleation. By default, the $\mathrm{C} 86$ ice nucleation parameterisation is used to represent the deposition-condensation nucleation of ice. When used together, these three modes of ice formation in their represented forms overpredict ice number concentrations over all surfaces, producing unrepresentative microphysics (not shown, Fig. S7). High ice number concentrations glaciate case 3 and completely suppress the liquid phase in case 1 . The influence of each of these modes of nucleation is discussed further in the Supplement.

To investigate the sensitivity of the modelled microphysics to predictable primary ice number concentrations, the Bigg (1953) immersion-freezing and Meyers et al. (1992) contactfreezing parameterisations were switched off within the microphysics scheme, and the sole contribution to $N_{\text {isg }}$ from one implemented parameterisation was considered. This relationship was varied in this study to test the cloud microphysical response. Deposition-condensation onset conditions commonly used in the WRF model $(T<-8$ and $S_{\mathrm{w}}>0.999$, or $\left.S_{\mathrm{i}}>1.08\right)$ were applied as a control simula-
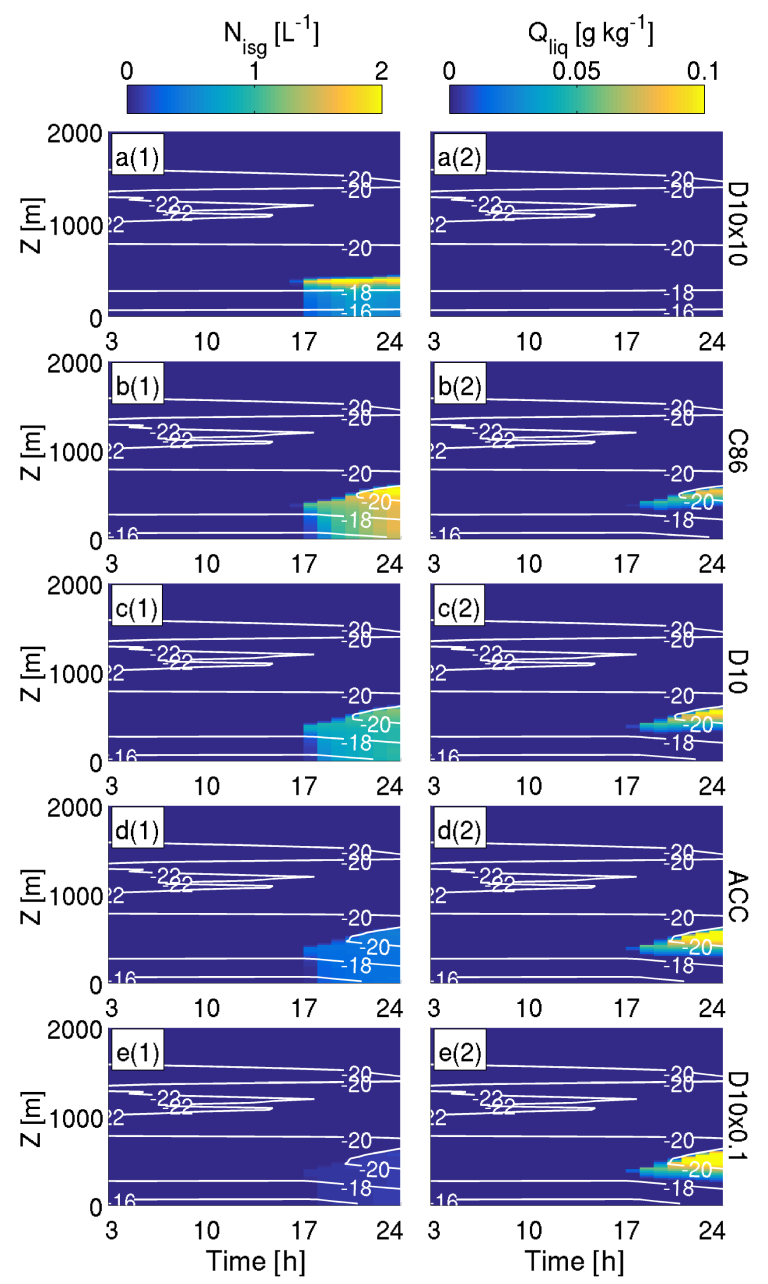

Figure 6. Simulated total ice number concentrations $\left(N_{\text {isg }}, \mathbf{a 1 - e 1}\right)$ and liquid water mixing ratios $\left(Q_{\text {liq }}, \mathbf{a} 2-\mathbf{e} 2\right)$ using the (a) D10 $\times 10$, (b) C86, (c) D10, (d) ACC, and (e) D10 $\times 0.1$ parameterisations for case 1 (sea ice). All are restricted to water saturation. Run length $24 \mathrm{~h}$. Temperature $\left({ }^{\circ} \mathrm{C}\right)$ contours are overlaid in white. Runs are arranged such that the simulation which produced the most ice $(\mathrm{D} 10 \times 10, \mathbf{a})$ is on the top row, and that which produced the least ice $(\mathrm{D} 10 \times 0.1, \mathbf{e})$ is on the bottom row. Note the changing colour bar at the top of each column, which corresponds to data in that column only.

tion for each case. Figure 5 shows the total ice number concentrations, $N_{\text {isg }}$, and liquid water mixing ratios, $Q_{\text {liq }}$, modelled over the sea ice (case 1), MIZ (case 2), and ocean (case $3)$.

Using C86 to represent deposition-condensation nucleation as a control for each case, the mixed-phase conditions observed over the MIZ (case 2) and the ocean (case 3) are captured by the model; however, no liquid is modelled over the sea ice (case 1, Fig. 5). Ice number concentrations of $\sim 3 \mathrm{~L}^{-1}$ are simulated at an altitude of approximately $1000 \mathrm{~m}$ for the first $10 \mathrm{~h}$ of the run, peaking at $3.4 \mathrm{~L}^{-1}$. This ice then dissipates, after which $N_{\text {isg }} \sim 1 \mathrm{~L}^{-1}$ is maintained be- 
Table 3. Maximum modelled values during each case for each parameterisation implemented at water saturation.

\begin{tabular}{llrrrrr}
\hline Case & Parameter & D10 $\times 10$ & C86 & D10 & ACC & D $10 \times 0.1$ \\
\hline \multirow{2}{*}{ Sea ice (case 1) } & $N_{\text {isg }}\left[\mathrm{L}^{-1}\right]$ & 2.89 & 2.32 & 1.29 & 0.47 & 0.13 \\
& $Q_{\text {liq }}\left[g_{\text { kg }}-1\right.$ & 0 & 0.09 & 0.10 & 0.14 & 0.16 \\
MIZ (case 2) & $N_{\text {isg }}\left[\mathrm{L}^{-1}\right]$ & 6.57 & 1.09 & 1.03 & 0.36 & 0.11 \\
& $Q_{\text {liq }}\left[\mathrm{g} \mathrm{kg}^{-1}\right]$ & 0.12 & 0.29 & 0.28 & 0.34 & 0.39 \\
Ocean (case 3) & $N_{\text {isg }}\left[\mathrm{L}^{-1}\right]$ & 15.5 & 3.83 & 3.01 & 0.71 & 0.37 \\
& $Q_{\text {liq }}\left[\mathrm{g} \mathrm{kg}^{-1}\right]$ & 0.10 & 0.32 & 0.32 & 0.36 & 0.38 \\
\hline
\end{tabular}

low $500 \mathrm{~m}$ for the remainder of the simulation. This sustained number concentration is of the same order of magnitude as the observations $\left(0.47 \pm 0.86 \mathrm{~L}^{-1}\right.$, Table 2$)$; however, mixedphase conditions are not modelled.

In contrast, co-existing regions of liquid and ice are simulated in cases 2 and 3 . Modelled $N_{\text {isg }}$ over the MIZ $\left(\sim 1.0 \mathrm{~L}^{-1}\right.$ at $1000 \mathrm{~m}$, Fig. $\left.5 \mathrm{~b}\right)$ is in reasonable agreement with the observed mean $\left(0.35 \pm 0.20 \mathrm{~L}^{-1}\right.$, Table 2). Persistent mixed-phase conditions are simulated in case 2 for approximately $16 \mathrm{~h}$. Such conditions are also attained in case 3 (Fig. 5c); however, modelled $N_{\text {isg }}$ peaks at $3.7 \mathrm{~L}^{-1}$ at $\sim 1450 \mathrm{~m}$, whereas only $0.55 \pm 0.95 \mathrm{~L}^{-1}$ was observed. This case glaciates after approximately $15 \mathrm{~h}$.

Cases 2 and 3 impose surface fluxes from the simulated ocean surface below; fluxes which induce turbulence in the modelled clouds. The lack of strong surface sensible and latent heat fluxes in case 1 restricts the formation of liquid water in the model as the second imposed criterion of ice supersaturation $\left(S_{\mathrm{i}}>1.08\right)$ is attained first. This modelled microphysics is unrepresentative of the observations during case 1. It is unlikely that the nucleation mechanisms involved in these clouds would differ substantially between the sea ice, MIZ, and ocean. Therefore, under the conditions commonly used in the WRF model, C86 overpredicts $N_{\text {isg }}$ and unsuccessfully reproduces the observed mixed-phase conditions over all three surfaces considered. To force the formation of persistent liquid in all cases, we restrict the formation of primary ice to water-saturated conditions in our subsequent simulations.

\subsection{Ice nucleation at water saturation}

\subsubsection{Case 1: Sea ice}

Figure 6 shows modelled $N_{\text {isg }}$ and liquid water mixing ratio, $Q_{\text {liq }}$, using the five parameterisations - D $10 \times 10, \mathrm{C} 86, \mathrm{D} 10$, ACC, and D $10 \times 0.1-$ over the sea ice. Vertical $(Z-Y)$ slices of $N_{\text {isg }}, Q_{\text {liq }}$, and $\mathrm{W}$ at $21 \mathrm{~h}$ are included in the Supplement (Fig. S8).

No liquid water is simulated when using D10 $\times 10$. A mixed-phase cloud is simulated below $600 \mathrm{~m}$ after $17 \mathrm{~h}$ in the remaining four simulations, with a liquid layer at cloud top with ice formation and precipitation below. Peak $Q_{\text {liq }}$ varies from C86 at the smallest $\left(0.09 \mathrm{~g} \mathrm{~kg}^{-1}\right)$, through D10 $\left(0.1 \mathrm{~g} \mathrm{~kg}^{-1}\right)$ and $\mathrm{ACC}\left(0.14 \mathrm{~g} \mathrm{~kg}^{-1}\right)$, to $\mathrm{D} 10 \times 0.1$ at the largest $\left(0.16 \mathrm{~g} \mathrm{~kg}^{-1}\right.$, Table 3$) . N_{\text {isg }}$ and $Q_{\text {liq }}$, with the exception of D10 $\times 10$, both increase with time as each cloud evolves. Modelled $N_{\text {isg }}$ varies through an order of magnitude, with maximum values of $2.89 \mathrm{~L}, 2.32,1.29,0.47$, and $0.13 \mathrm{~L}^{-1}$ attained by $\mathrm{D} 10 \times 10, \mathrm{C} 86, \mathrm{D} 10, \mathrm{ACC}$, and D10 $\times 0.1$ respectively.

Figure 7 shows a comparison between measured and modelled $N_{\text {ice }}>100 \mu \mathrm{m}$ and $Q_{\text {liq }}$ for each case when using C86, D10, and ACC. 2DS data have poor resolution at small sizes $(<80 \mu \mathrm{m})$, preventing the particle shape factor from being accurately determined at these sizes (Crosier et al., 2011; Taylor et al., 2016; Young et al., 2016a); therefore, the number concentration of small ice crystals is not a reliable measure with this instrument. For this reason, the observed number concentration of ice crystals greater than $100 \mu \mathrm{m}$ are directly compared with modelled ice and snow particles in this size range. Figure $7 \mathrm{a}$ shows this comparison using the C86, D10, and ACC parameterisations for case 1. Mean parameters modelled at $21 \mathrm{~h}$ during case 1 are shown in Fig. 7a, d. The empirically derived ACC relationship produces $N_{\text {ice }}>100 \mu \mathrm{m}$ and $Q_{\text {liq }}$ profiles comparable to the observed mean as expected (Fig. 7a, d), suggesting that ice particle growth rates are adequately represented, whilst D10 and C86 overpredict $N_{\text {ice }}>100 \mu \mathrm{m}$ and marginally underpredict $Q_{\text {liq. }}$. Comparisons including D $10 \times 10$ and D $10 \times 0.1$ and the method for choosing these time steps are detailed in the Supplement (Figs. S11, S12).

Liquid and ice water paths (LWP and IWP, respectively) using each parameterisation are shown in Fig. 8a, d. Both increase with model time when using each of the parameterisations. D10 $\times 0.1$ produces the highest LWP and lowest IWP. D10 $\times 10$ produces no liquid - giving a LWP of zero and the simulated IWP increases initially (between approximately 17 and $20 \mathrm{~h}$ ), but subsequently decreases as the $N_{\text {isg }}$ falls out from the cloud layer. The D10 and C86 parameterisations produce similar trends in the LWP and IWP traces, resulting in approximately $15-20$ and $2-3 \mathrm{~g} \mathrm{~m}^{-2}$ respectively by $24 \mathrm{~h}$.

Negligible surface fluxes were applied in this case; therefore, cloud dynamics was driven primarily by longwave radiative cooling (similar to Ovchinnikov et al., 2011). In the 

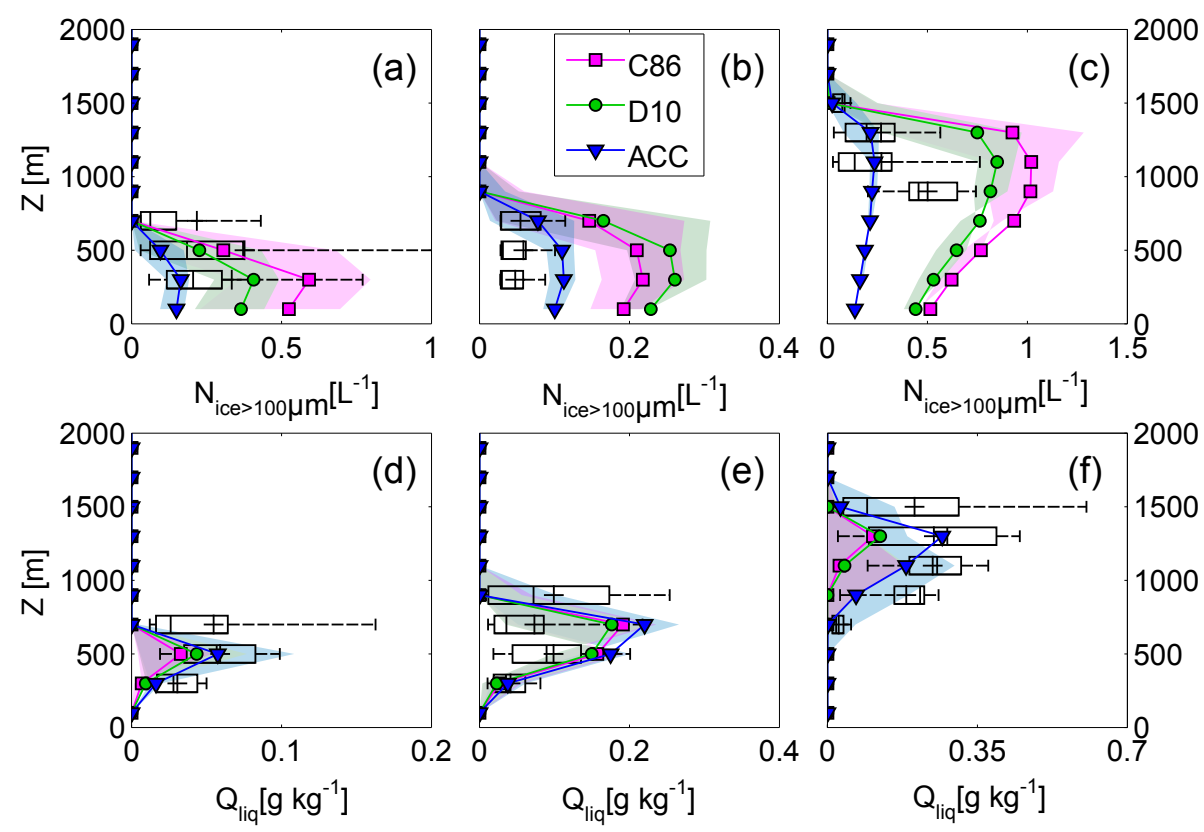

Figure 7. Observed $N_{\text {ice }}>100 \mu \mathrm{m}$ and $Q_{\text {liq }}$ for the sea ice (column 1), MIZ (column 2), and ocean (column 3) cases. Observations are shown as black boxes, similar to Fig. 4. Mean modelled concentrations of ice and snow particles greater than $100 \mu \mathrm{m}$, using the C86 (magenta), D10 (green), and ACC (blue) parameterisations, are overlaid. Model time steps of 21, 17, and $7 \mathrm{~h}$ are used for the sea ice, MIZ, and ocean cases respectively, as these time steps offer the best comparison with the observations. Shading (in pink, green, or blue for C86, D10, and ACC respectively) indicates variability in the model parameters from $\pm 3 \mathrm{~h}$ in cases 1 and 2 , and $\pm 4 \mathrm{~h}$ in case 3 , where a larger interval is implemented in the latter case as the chosen parameters showed little variability over the shorter time step. In panel (f), the variability illustrated is always less than the mean modelled profile shown using each parameterisation as the $Q_{\text {liq }}$ is at its greatest at the chosen time step. Observed $N_{\text {ice }}>100 \mu \mathrm{m}$ data from noted shattering event (Young et al., 2016a) are excluded in panel c, so that only primary contributions of ice are considered.

observations, a lack of strong turbulent motions within this mixed-phase cloud layer caused a suppressed LWMR in the vicinity of moderate ice number concentrations (Young et al., 2016a). The LEM reproduces these conditions well in the absence of strong surface fluxes, as a small $Q_{\text {liq }}$ and a reasonable $N_{\text {isg }}$ are modelled under the restriction of watersaturated ice nucleation.

\subsubsection{Case 2: Marginal ice zone}

All parameterisations produce a mixed-phase, sustained cloud layer over the MIZ (case 2, Fig. 9). Modelled LWPs and IWPs are larger in case 2 than in case 1. Strong surface fluxes are implemented in case 2 to represent a comparatively warm ocean at the surface, allowing turbulent motions to sustain a greater $Q_{\text {liq }}$ within the mixed-phase cloud layer (Morrison et al., 2008).

Figure 9 shows that there is little variation between the simulations, except when implementing D $10 \times 10 . N_{\text {isg }}$ of up to $6.6 \mathrm{~L}^{-1}$ are simulated using $\mathrm{D} 10 \times 10$, with a suppressed $Q_{\text {liq }}$ (Fig. 9a). C86 and D10 perform similarly, predicting a $N_{\text {ice }}$ of $0.23 \mathrm{~L}^{-1} / 0.34 \mathrm{~L}^{-1}$ respectively at the CTT (Table 1), and producing comparable peak $N_{\text {isg }}$ and $Q_{\text {liq }}$ values (Table 3) when implemented in the model. Similar liquid $\left(\sim 100 \mathrm{~g} \mathrm{~m}^{-2}\right)$ and ice water paths $\left(\sim 7 \mathrm{~g} \mathrm{~m}^{-2}\right)$ are also modelled by the end of each simulation (Fig. 8b, e). $Q_{\text {liq }}$ agrees reasonably well with observations when implementing C86 and D10 (Fig. 7e); however, both overpredict $N_{\text {ice }>100 \mu m}$, suggesting that the modelled ice is growing too efficiently. This overprediction of $N_{\text {ice }}>100 \mu \mathrm{m}$ may be due to the modelled temperature being lower than was observed (see Table 1 and Fig. 9).

ACC also produces a sustained, mixed-phase cloud layer in case 2; however, a significantly greater $Q_{\text {liq }}$ is modelled than is observed $\left(0.22 \mathrm{~g} \mathrm{~kg}^{-1}\right.$, compared with $0.07 \mathrm{~g} \mathrm{~kg}^{-1}$, at $700 \mathrm{~m}$ in Fig. 7e). This suggests that the simulated ice number concentration is not sufficient enough to suppress the formation of liquid with this relationship. ACC marginally overpredicts $N_{\text {ice }}>100 \mu \mathrm{m}$ compared to observations $\left(0.13 \mathrm{~L}^{-1}\right.$ versus $0.03 \mathrm{~L}^{-1}$, Fig. $7 \mathrm{~b}$ ), whereas the greater $N_{\text {ice }}>100 \mathrm{um}$ concentrations modelled by C86 and D10 suppress the $Q_{\text {liq }}$ more effectively, improving agreement with the observations. $\mathrm{D} 10 \times 0.1$ produces the lowest $N_{\text {isg }}$ overall $\left(0.11 \mathrm{~L}^{-1}\right.$, Fig. 9e), producing the greatest $Q_{\text {liq }}$ out of all of the simulations $\left(0.39 \mathrm{~g} \mathrm{~kg}^{-1}\right.$, Table 3$)$. 

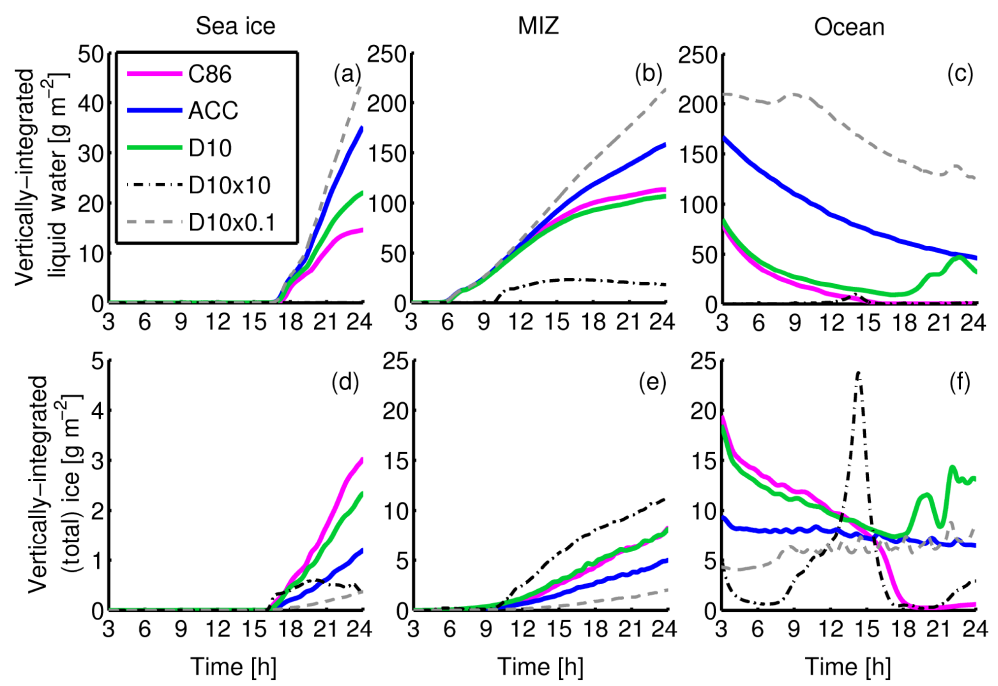

Figure 8. Vertically integrated liquid (a-c) and ice water paths (d-f) for the sea ice, MIZ, and ocean cases when implementing each of the C86, ACC, D10, D10 × 10, and D10 × 0.1 parameterisations under water-saturated conditions.

\subsubsection{Case 3: Ocean}

Over the ocean (case 3), strong sensitivities to $N_{\text {isg }}$ emerge (Fig. 10). D10 $\times 10$ simulates a high $N_{\text {isg }}$, producing repetitive glaciating events. Little liquid water is produced throughout $\left(\sim 0.1 \mathrm{~g} \mathrm{~kg}^{-1}\right)$; however, small increases are modelled alongside the glaciating bursts. C86 allows a mixed-phase cloud layer to form for some time, approximately $17 \mathrm{~h}$, after which it glaciates due to accumulated $N_{\text {isg. }}$. Liquid water is only simulated at cloud top until this point. Glaciation does not occur with D10, despite predicting only $\sim 0.4 \mathrm{~L}^{-1}$ less $N_{\text {ice }}$ at the CTT than C86 (Table 1). D10 allows for mixed-phase conditions to be maintained for the full $24 \mathrm{~h}$ duration of the run; however, $Q_{\text {liq }}$ is underestimated (Fig. 7f). As with cases 1 and 2, both C86 and D10 overpredict $N_{\text {ice }}>100 \mu \mathrm{m}$ at the chosen time step (Fig. 7c).

$\mathrm{ACC}$ and $\mathrm{D} 10 \times 0.1$ also produce a mixed-phase cloud layer; however, more liquid and less ice is modelled in these simulations. ACC produces comparable $N_{\text {ice }}>100 \mu \mathrm{m}$ and $Q_{\text {liq }}$ to observations as expected when not considering the shattering event at cloud base (Fig. 4c) and predicts $0.54 \mathrm{~L}^{-1}$ at the case 3 CTT. D10 $\times 0.1$ produces reasonable agreement with the $Q_{\text {liq }}$ observations at $7 \mathrm{~h}$ (Fig. S11); however, the rapidly increasing cloud-top height and $Q_{\text {liq }}$ with time are not representative of the observations. D $10 \times 0.1$ produces peak $N_{\text {isg }}$ values that are almost a factor of 2 lower than observed for case $3\left(0.37 \mathrm{~L}^{-1}\right)$, allowing the greatest peak $Q_{\text {liq }}$ to form out of the five parameterisations considered $\left(0.38 \mathrm{~g} \mathrm{~kg}^{-1}\right.$, Fig. 10e, Table 3). This $Q_{\text {liq }}$ is high in comparison to the ACCACIA observations (Table 2); however, $N_{\text {isg }}$ is in better agreement than the D10 simulations in this case.

Cloud forms and begins to decay immediately in case 3, as shown by the decreasing LWPs modelled (Fig. 8c), caused by the moist $\mathrm{BL}$ and a high $N_{\text {isg }}$ which acts as an effi- cient sink for liquid by the WBF mechanism. Most of the simulations also produce a decreasing IWP (Fig. 8f); however, a consistent IWP is modelled with ACC and D10 $\times 0.1$. The rapid glaciating events modelled with $\mathrm{D} 10 \times 10$ (shown in Fig. 10a) can again be seen in the IWP, with a maximum value of nearly $25 \mathrm{~g} \mathrm{~m}^{-2}$ attained at approximately $14 \mathrm{~h}$ (Fig. 8f). Due to the strong dependence of $N_{\text {ice }}$ on temperature, high $N_{\text {isg }}$ are created which readily undergo depositional growth, deplete the vapour field, and fall from the cloud once the particles transition to the snow category. The vapour field recovers due to the moisture fluxes from the surface, and the process repeats once water and ice supersaturation are attained. The LWP is zero for the majority of this simulation; however, a small amount of liquid also forms at $14 \mathrm{~h}$. As with case 2, D10 and C86 produce similar IWP and LWPs in case 3; however, these diverge at approximately $17 \mathrm{~h}$ when the $\mathrm{C} 86$ case glaciates (Fig. 8c, f).

\section{Discussion}

\subsection{Cloud glaciation}

Over the ocean (case 3), C86 leads to cloud glaciation when freezing is implemented under both deposition-condensation (Fig. 5c) and water-saturated (Fig. 10b) conditions. This cloud glaciation is tied to the number of ice crystals produced: over the temperature range shown in Fig. 1, D10 $\times 10$ and C86 typically produce the most ice; therefore rapid ice formation is simulated once the onset thresholds are reached. The high $N_{\text {isg }}$ suppresses the liquid phase within the cloud layers, either immediately $(\mathrm{D} 10 \times 10)$ or after an accumulation period (C86). However, D10 produces a similar $N_{\text {ice }}$ $\left(2.07 \mathrm{~L}^{-1}\right)$ to $\mathrm{C} 86\left(2.42 \mathrm{~L}^{-1}\right.$, Table 1$)$ at the CTTs consid- 


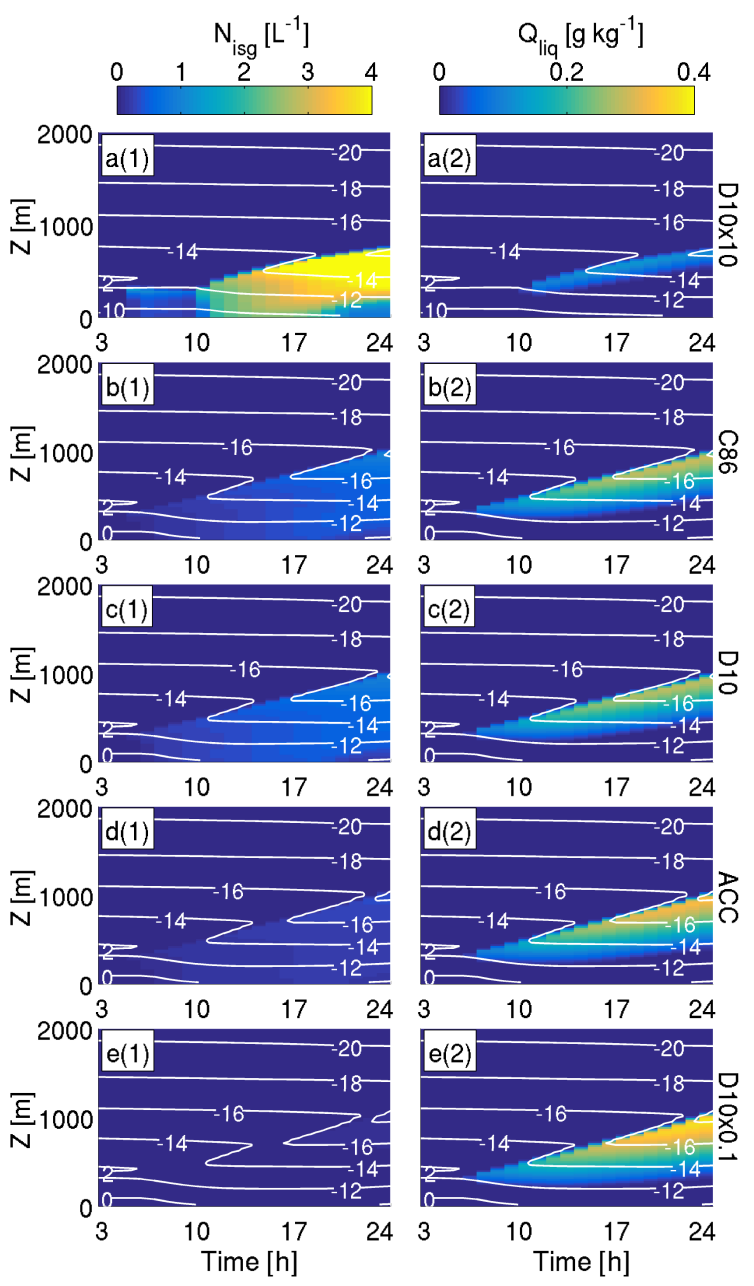

Figure 9. MIZ (case 2) simulations, presented similarly to Fig. 6.

ered. This subtle difference in predicted ice number allows the D10 cloud to persist, whilst the C86 cloud glaciates. Similarly, D10 $\times 10$ does not allow liquid water to ever form in case 1 , but allows for mixed-phase conditions, albeit with a highly suppressed $Q_{\text {liq }}$, to be modelled in case 2 .

\subsection{Cloud break-up}

Whilst D10 produces a persistent mixed-phase cloud for the full duration, peculiar trends appear at times $>20 \mathrm{~h}$. Figure 8 shows the development of peaks and troughs in the IWP, with corresponding peaks in the LWP, after this time. To investigate these LWP and IWP trends further, Fig. 11 shows $X-Y$ planar views of each simulated parameterisation at $21 \mathrm{~h}$ : LWP and IWP are total integrated values over the full height of the domain, and the vertical velocity, $W$, is chosen at approximately cloud top $(1500 \mathrm{~m})$. Little variation can be seen in D10 $\times 10$ (Fig. 11a) and C86 (Fig. 11b) at this time as $N_{\text {isg }}$ and $Q_{\text {liq }}$ have dissipated and not yet reformed.

Co-located hotspots of IWP, LWP, and W can be seen in the D10 simulation (Fig. 11c). These localised regions of

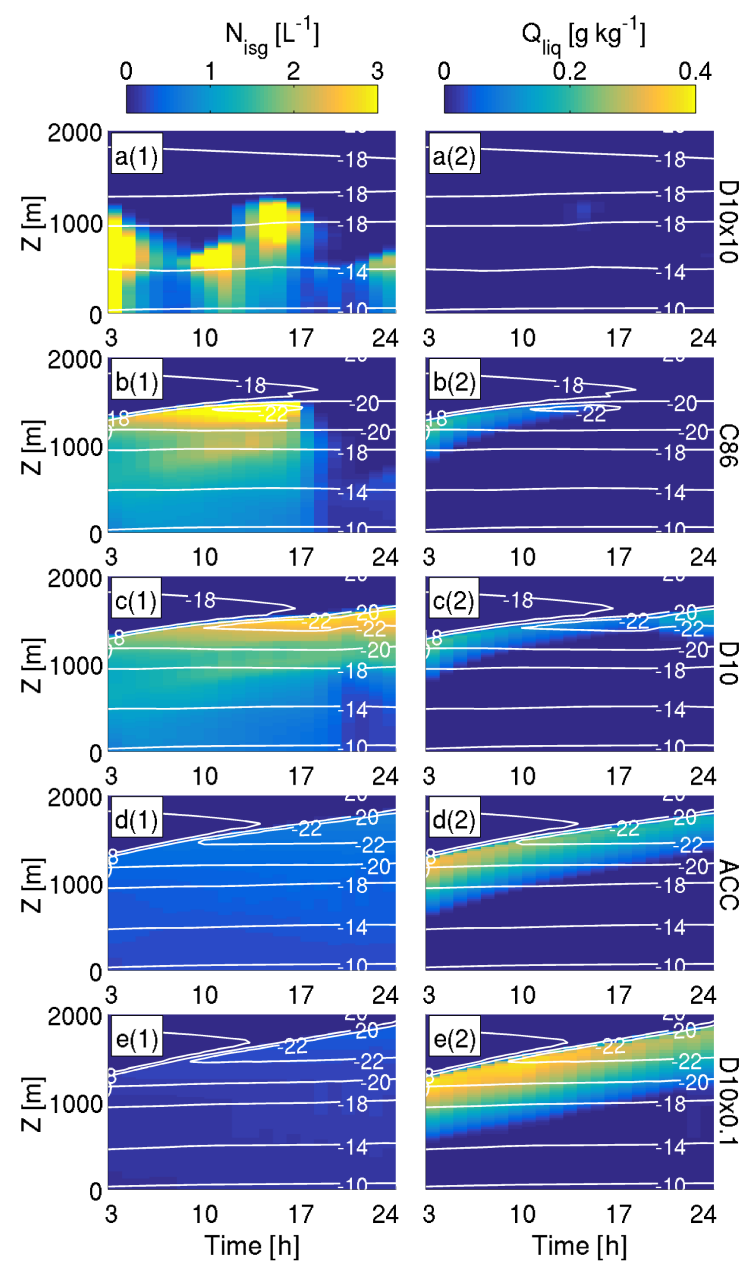

Figure 10. Ocean (case 3) simulations, presented similarly to Figs. 6 and 9.

increased ice and/or liquid result from isolated convective cells within the cloud. The formation of these cells forces the cloud top higher (Fig. 10c), with renewed liquid and ice formation. Strong updraughts are modelled in close vicinity to enhanced downdraughts. Similar defined structures can be seen in D10 $\times 0.1$ (Fig. 11e); however, these appear mostly in the LWP field and have an elongated, banded shape in comparison to the compact, almost circular, structures which evolve in D10. This elongated band of increased LWP in $\mathrm{D} 10 \times 0.1$ mirrors a region of isolated downdraughts. In contrast, regions of high LWP or IWP are not seen in the ACC case (Fig. 11d)

The simulations presented in Fig. 11c, d, e were considered further. The D10 case produces the most ice and least liquid of the three, with $\mathrm{D} 10 \times 0.1$ vice versa. The convective regions of $\mathrm{D} 10$ and $\mathrm{D} 10 \times 0.1$ can be linked to an increased number concentration of large precipitable particles (Fig. 12). Specifically, greater number concentrations of large solid (snow + graupel) hydrometeors are modelled using D10, whilst more large liquid (rain) hydromete- 


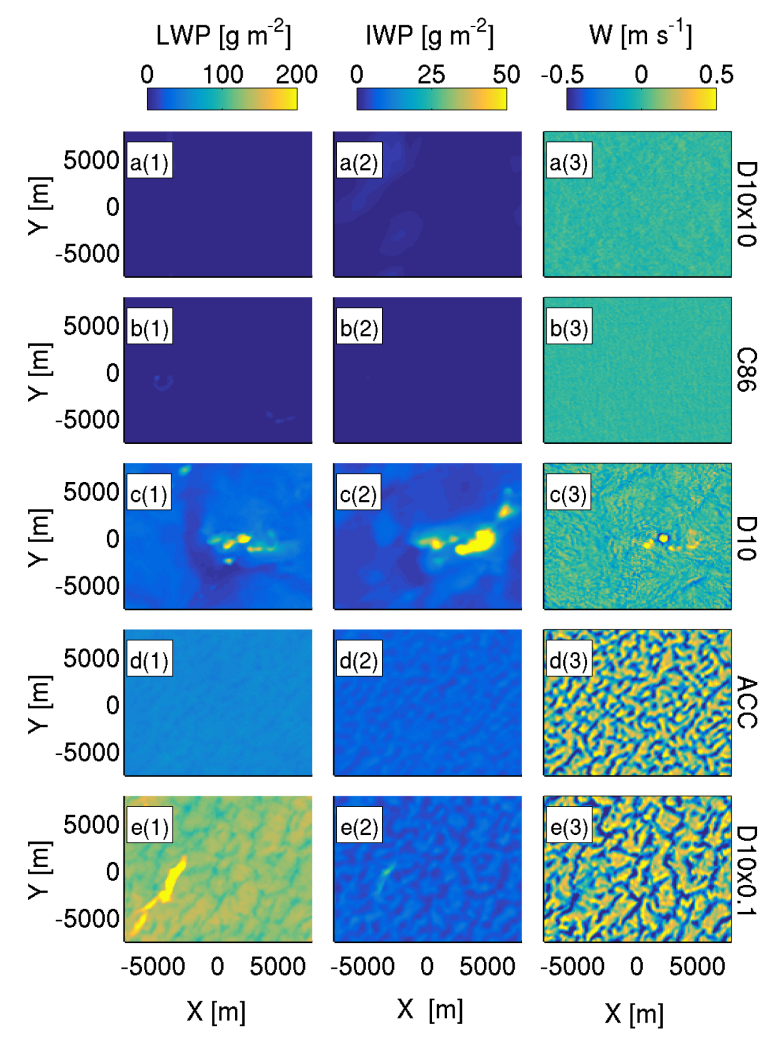

Figure 11. LWP (a1-e1), IWP (a2-e2), and vertical velocity (W, a3-e3) at approximately $1500 \mathrm{~m}$ for each simulation in the ocean case. Planar $X-Y$ slices are shown at $21 \mathrm{~h}$. Note changing colour bar at the top of each column, which corresponds to data in that column only.

ors are modelled in $\mathrm{D} 10 \times 0.1$. Rain particles evaporate below cloud in all simulations and do not reach the surface. With D10, a greater number concentration of solid precipitating particles (up to $1 \mathrm{~L}^{-1}$ ) is modelled than in the ACC $\left(0.29 \mathrm{~L}^{-1}\right)$ or $\mathrm{D} 10 \times 0.1\left(0.17 \mathrm{~L}^{-1}\right)$ simulations. Similarly, significantly larger concentrations of rain particles are modelled (up to $27 \mathrm{~L}^{-1}$ ) in the $\mathrm{D} 10 \times 0.1$ simulation in comparison to ACC $\left(17 \mathrm{~L}^{-1}\right)$ or D10 $\left(12 \mathrm{~L}^{-1}\right)$. In comparison to D10 and $\mathrm{D} 10 \times 0.1$, ACC produces fewer solid and liquid precipitating particles respectively. Number concentrations of large precipitable particles modelled during cases 1 and 2 are shown in the Supplement (Fig. S15).

The formation of convective cells in the ocean case mirrors cold air outbreak observations: as cold air moves from over the sea ice to the ocean, the boundary layer becomes thermodynamically unstable, allowing temperature perturbations to cause strong positive feedbacks on the cloud structure. Mixed-phase clouds are sustained by moderate vertical motions (e.g. Shupe et al., 2008a, b), driven by latent heating from hydrometeor growth within the cloud and radiative cooling at cloud top (Pinto, 1998; Harrington and Olsson, 2001). At the cold temperatures considered (approxi-

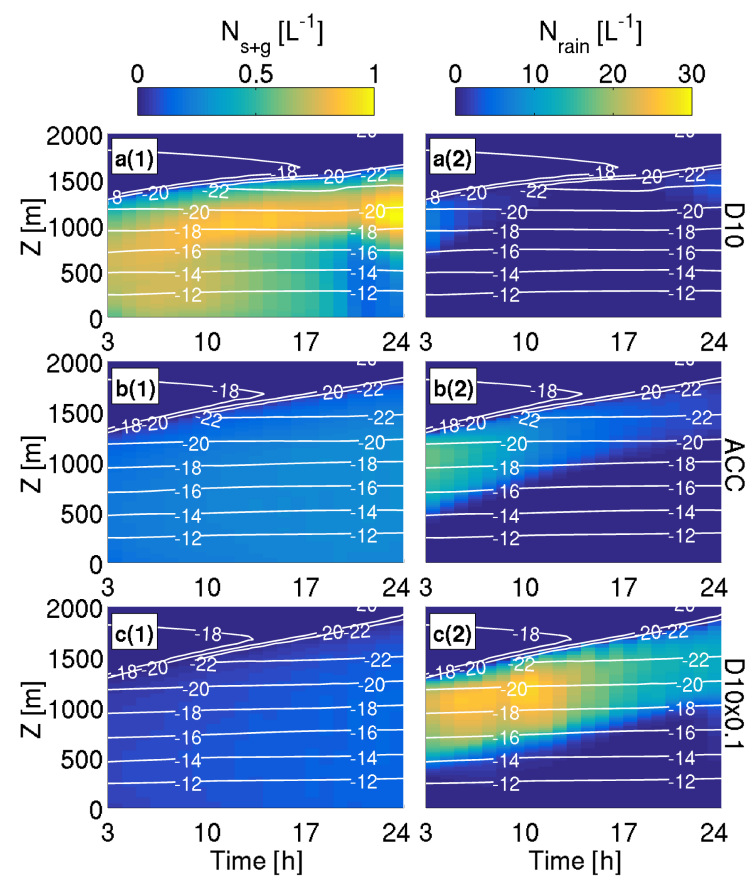

Figure 12. Summed snow and graupel number concentrations $\left(N_{\mathrm{s}+\mathrm{g}}, \mathbf{a 1 - c 1}\right)$ and rain number concentration $\left(N_{\text {rain }}, \mathbf{a 2 - c 2}\right)$ using (a) D10, (b) ACC, and (c) D10 $\times 0.1$ during case 3 . Run length $24 \mathrm{~h}$. Temperature $\left({ }^{\circ} \mathrm{C}\right)$ contours are overlaid in white. Note changing colour bar at the top of each column, which corresponds to data in that column only.

mately $-20^{\circ} \mathrm{C}$ ), ice grows favourably by vapour growth in the vicinity of liquid droplets and, given a high enough $N_{\text {isg }}$, updraughts are enhanced through latent heat release. With enforced updraughts, water supersaturations are sustained, more cloud droplets form, and cloud top is forced to higher altitudes. With more liquid and a higher cloud top, enhanced radiative cooling strengthens downdraughts adjacent to the updraught columns. With a deeper cloud layer, precipitation can form by an increased likelihood of collision-coalescence of droplets (or ice crystal growth and aggregation), within the downdraughts. The formation of precipitation warms and dries the cloud, reinforcing the updraughts and recycling the process. In the D10 ocean case - with high ice number concentrations, but not high enough for glaciation - the accumulation of $N_{\text {isg }}$ promotes this pathway, with the development of precipitation being the key factor in the localised, runaway convection that occurs.

With the development of precipitable particles as snow and graupel or rain, $Q_{\text {liq }}$ is depleted from the cloud layer. The D10 case produces high number concentrations of snow, which depletes $Q_{\text {liq }}$ efficiently. Once the convective activity starts in this case, the cloud liquid is depleted; however, it is also partially restored through sustained supersaturations in the strong updraughts. In the $\mathrm{D} 10 \times 0.1$ case, the $Q_{\text {liq }}$ depletion is slower as rain is less efficient at removing droplets 


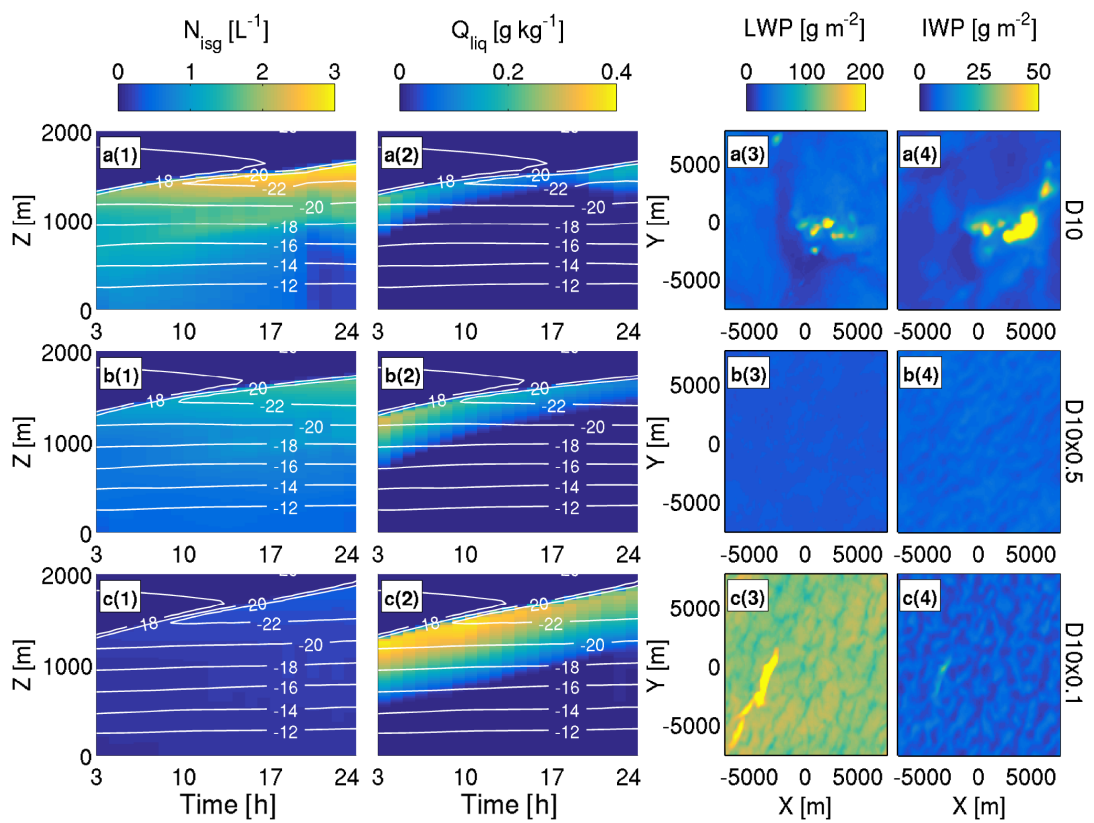

Figure 13. $N_{\text {isg }}$ (a1-c1), $Q_{\text {liq }}(\mathbf{a} 2-\mathbf{c} 2)$, LWP (a3-c3), and IWP (a4-c4) modelled in the (a) D10, (b) D10 $\times 0.5$, and (c) D10 $\times 0.1$ simulations over the ocean (case 3). Data are presented similarly to Figs. 10 and 11 . Temperature $\left({ }^{\circ} \mathrm{C}\right)$ contours overlaid in white in panels 1 and 2 . Note changing colour bar at the top of each column, which corresponds to data in that column only.

than snow. Both of these precipitation pathways would therefore likely lead to cloud break-up if the simulation time was extended further.

Given the two pathways of precipitation identified by Fig. 12, a question arose: do these structures form as a result of the functional form of D10, or are they related simply to ice number? ACC produced an $N_{\text {isg }}$ between D10 and $\mathrm{D} 10 \times 0.1$, and no heterogeneous structures were modelled. Therefore, to address this question, $\mathrm{D} 10 \times 0.5$ was imposed in the LEM. For comparison with Table $1, \mathrm{D} 10 \times 0.5$ predicts $1.04 \mathrm{~L}^{-1}$ at the CTT. Figure 13 illustrates modelled $N_{\text {isg }}$ and $Q_{\text {liq }}$ for the D10, D $10 \times 0.5$, and D $10 \times 0.1$ simulations over the ocean. LWP and IWP modelled at $21 \mathrm{~h}$ are also shown. $\mathrm{D} 10 \times 0.5$ produces less ice than $\mathrm{D} 10$ and less liquid than $\mathrm{D} 10 \times 0.1$ : this simulation behaves as expected to give the microphysical midpoint between these scenarios. Therefore, the modelled cloud persistence and stability is not just a feature of ACC. A homogeneous cloud structure is modelled with $\mathrm{D} 10 \times 0.5$ and the localised hotspots of the D10 and D10 $\times 0.1$ cases are not present. Such hotspots do not form in the D10 $\times 0.5$ simulation. Modelled number concentrations of precipitating particles using this parameterisation (Fig. S17) are significantly less than D10 (snow + graupel) and D10 $\times 0.1$ (rain), and the simulated cloud persists for the full $24 \mathrm{~h}$ duration with no break-up.

Additionally, a larger domain size was imposed to test whether these convective cells were related to the imposed cyclical boundary conditions: both similar structures and LWP / IWP trends formed (not shown, Figs. S18, S19), sug- gesting these convective cells are not simply a result of the domain configuration. Within the timescales imposed in this study $(24 \mathrm{~h})$, these cells are only observed over the ocean (case 3). Given more time ( $33 \mathrm{~h}$ ), case 2 also develops convective cells and increased concentrations of large hydrometeors when D10 and D10 $\times 0.1$ are imposed (not shown, Figs. S20-S23). Therefore, we conclude that - in two of the ACCACIA cases considered, which occurred on different days, under different synoptic conditions, with different air mass histories (Young et al., 2016b) - model simulations using the D10 ice nucleation parameterisation can produce localised cellular structure within the mixed-phase cloud layer, given enough time to do so.

The development of appreciable precipitation is particularly sensitive to ice number in this study. ACC and $\mathrm{D} 10 \times 0.5$ maintain mixed-phase conditions for $24 \mathrm{~h}$ over the ocean, with no cell development and little precipitation (Fig. 13), suggesting there is an optimal $N_{\text {isg }}$ for cloud persistence in this case. Glaciation occurs with C86, persistence is achieved with $\mathrm{D} 10 \times 0.5$ and $\mathrm{ACC}$, and convective cells form in D10 and D10 $\times 0.1$. It is unclear which representation is correct in this environment, as observations do show the development of convection in cold air outbreak scenarios as the cold air masses move over the warm ocean (e.g. Hartmann et al., 1997). Additionally, snow precipitation was observed by Young et al. (2016a) in this case. It cannot be stated whether the timescales of convection development modelled here are good representations of this phenomenon. 


\subsection{Cloud-top height}

Cloud-top height clearly increases with model time in cases 1 and 2, and more subtly in case 3. Large-scale subsidence, which would act to suppress cloud-top ascent, was not imposed in these simulations. This increasing cloud top was observed by Young et al. (2016a) over the transition from sea ice to ocean; therefore, the modelled cloud structure is in reasonable agreement with observations without largescale subsidence imposed. However, the temperatures simulated in case 2 (Fig. 9) are colder than observed (Table 1). As a result, the $N_{\text {ice }}>100 \mu m$ modelled with the considered temperature-dependent parameterisations is greater than observed (Fig. 7b). Overall, the $N_{\text {isg }}$ is in reasonable agreement with the observed $N_{\text {ice }}$ (Tables 2, 3), likely due to the low concentrations of snow and graupel produced at the warm subzero temperatures considered, and it is probable that this agreement would improve further if the modelled temperature was accurate. In contrast to cases 1 and 3, the reasonable agreement of $N_{\text {isg }}$ and poorer agreement of $N_{\text {ice }}>100 \mu \mathrm{m}$ suggests that the ice crystal growth rates may be too efficient in case 2 . Additionally, case 2 occurred on a different day to cases 1 and 3; therefore, different synoptic conditions were influencing the sampled cloud systems. Increasing the modelled large-scale subsidence acts to increase the modelled temperatures slightly (not shown, Fig. S16); however, a substantial subsidence would be required to match the observations in this case. Given that imposing large-scale subsidence increases the temperature and suppresses $Q_{\text {liq }}$, without greatly affecting $N_{\text {isg }}$, we suggest that a greater imposed subsidence may improve the agreement with the observations in case 2 .

Cloud top reaches higher altitudes in the ACC and D10 $\times 0.1$ simulations across all surfaces compared to D10, $\mathrm{C} 86$, and $\mathrm{D} 10 \times 10$, due to a greater liquid water content: as more liquid forms from the vapour field, more heat is released, pushing the cloud top higher. These liquiddominated cases are also shown to experience enhanced convection across the full domain in case 3 (Fig. 11). With increased cloud-top height, enhanced radiative and evaporative cooling enforce downdraughts whilst increased latent heat release from droplet formation and growth strengthens updraughts. In the $\mathrm{C} 86, \mathrm{D} 10$, and $\mathrm{D} 10 \times 10$ simulations, a greater $N_{\text {isg }}$ suppresses efficient droplet growth, latent heat release, cloud-top ascent, and strong radiative cooling through the WBF mechanism. This finding is in agreement with Harrington and Olsson (2001), who showed that a high $N_{\text {isg }}$ produces weaker BL convection and a shallower $\mathrm{BL}$, whilst liquid-dominated mixed-phase clouds promote a higher cloud top and deeper BL.

\subsection{Relationship with predicted INPs: DeMott et al. (2010)}

Of the two established parameterisations considered (Cooper, 1986; DeMott et al., 2010), D10 produces better agreement with the observed ice and liquid in all cases (Table 3). In particular, it does reasonably well at predicting the lower ice number concentrations observed during cases 1 and 2.

D10 predicts the number of INPs - not ice crystals - active at a given temperature, $T_{\mathrm{K}}$. Though reasonable agreement is found with observations, D10 still produces too much $N_{\text {isg }}$ in each case (Figs. 6c, 9c, and 10c). D10 predicts approximately double and quadruple the number of ice crystals observed at the respective CTTs in cases 1 and 3 (Tables 1 and 2). Young et al. (2016b) found a large fraction of super-micron sea salt particles over the sea ice (case 1) and below the MIZ cloud (case 2). No filter data were available for the ocean case (case 3); however, it can be assumed that a similar fraction of these aerosol particles may also be sea salt, given they were found upstream over the sea ice under the same meteorological conditions (Young et al., 2016a). Given these results, it is not surprising that D10 overestimates the quantity of supermicron INPs available to nucleate ice in these conditions, as sea salt is an inefficient INP and constitutes a large fraction of $n_{\text {aer }, 0.5 \text {. }}$

Additionally, an approximation of D10 was applied. The average aerosol number concentration $\left(0.5<D_{\mathrm{P}} \leq 1.6 \mu \mathrm{m}\right.$, DeMott et al., 2010) in each case was used to evaluate Eq. (2) to give a temperature-dependent function. This idealised scenario would only be representative of a region where the aerosol particle number concentration was being replenished and INPs were not depleted. Additionally, a constant input of aerosol particle number concentration was used in Eq. (2), irrespective of altitude in the model; therefore, spatial variability of INPs in the boundary layer was not represented. Particle number concentrations typically decrease with altitude away from local surface sources; therefore, this approximation of vertical homogeneity may also be positively influencing the number concentration of ice crystals predicted by D10.

\subsection{ACCACIA observational fit: ACC}

For the three case studies considered, the empirically derived ACC relationship produces a similar number concentration of large ice crystals $(>100 \mu \mathrm{m})$ as are observed. This suggests that the efficiency of ice growth is actually well represented by the microphysics scheme. As this relationship is a fit derived from our observations, a good comparison between total ice number concentrations are expected, and the $N_{\text {ice }}$ predicted at the CTT agrees well with the observed mean (Tables 1,2). Modelled $N_{\text {isg }}$ allows for stable mixed-phase conditions to be simulated in each case; however, the liquid phase of the cloud is overpredicted in comparison to observa- 
tions in each case (Table 3). This is particularly clear in case 2 (Fig. 7e). Too few ice crystals are modelled to sufficiently deplete the liquid phase via the WBF mechanism. The modelled ice crystal growth rates - which allow for a good comparison between modelled and observed large ice number concentrations - do not act to adequately suppress the liquid phase in this case. Ice crystal habits are not explicitly resolved in the microphysics scheme, and the resultant variable growth rates could act to suppress the modelled $Q_{\text {liq. }}$. Habits which undergo efficient vapour growth (e.g. stellar dendrites or sector plates; Mason, 1993) would allow increased ice mass to be modelled, with a consistent $N_{\text {isg }}$ and a suppressed $Q_{\text {liq }}$.

This relationship was derived using data from five springtime ACCACIA flights; therefore, the small sample size restricted the range over which a relationship could be established. Further observations could allow this relationship to be validated and potentially extended further; however, based on these ACCACIA data, this curve is not applicable beyond $252 \mathrm{~K}<T_{\mathrm{K}}<265 \mathrm{~K}$. Temperatures colder than this limit are modelled in case 3 due to increasing cloud-top height and strong radiative cooling; therefore, these results must be interpreted with caution. ACC produces stable mixed-phase conditions in all cases; however, it could potentially be overpredicting this stability and it may not adequately allow for cloud break-up downstream. This could have implications for the radiative budget of the region; therefore, the ability of ACC to allow for eventual cloud break-up should be tested in further work.

\subsection{Cloud persistence}

As shown by previous studies (Harrington and Olsson, 2001; Morrison et al., 2011; Ovchinnikov et al., 2011, amongst others), the microphysical structure of Arctic MPS is highly sensitive to ice crystal number. Greater ice number concentrations enhance the efficiency of the WBF process - leading to the depletion of liquid water within the cloud - whilst lower number concentrations allow liquid droplets to persist under moderate vertical motions. Mixed-phase conditions are sustained for at least $8 \mathrm{~h}$ in all three cases when imposing the three main ice nucleation parameterisations - ACC, D10, and C86 - under water-saturated conditions. By additionally considering the sensitivity tests $(\mathrm{D} 10 \times 10$, and $\mathrm{D} 10 \times 0.1)$, we can suggest limitations of $N_{\text {ice }}$ which maximise cloud persistence in each case, based on the predictions at the cloud-top temperature (Table 1).

Optimal mixed-phase cloud persistence and comparable microphysics are modelled in case 1 with $0.51 \mathrm{~L}^{-1} \quad$ (ACC) $<N_{\text {ice }(\text { CTT })}<1.31 \mathrm{~L}^{-1} \quad$ (D10) over the sea ice (Fig. 6, 7). With reference to the observed $N_{\text {ice }}$ $\left(0.47 \pm 0.86 \mathrm{~L}^{-1}\right.$, Table 2$)$, the upper limit proposed here is more than twice the mean value, but is still within 1 standard deviation. In case 2 , the low temperatures modelled affect our recommendation. The best predictions of $N_{\text {ice }}$ in comparison to our observations $(0.35 \pm 0.20$, Table 2$)$ are obtained with C86 $\left(0.23 \mathrm{~L}^{-1}\right)$ and D10 $\left(0.34 \mathrm{~L}^{-1}\right)$ when considering the observed CTT. However, the most comparable microphysical representation (from Fig. 7b, e) is achieved when using ACC, which predicts an $N_{\text {ice }}$ of $0.17 \mathrm{~L}^{-1}$ at the observed CTT but produces a peak $N_{\text {isg }}$ of $0.36 \mathrm{~L}^{-1}$ at the colder modelled temperatures. We suggest that $\mathrm{C} 86$ and/or D10 would perform better than ACC if the modelled temperature was more comparable with observations in this case. Finally, steady mixed-phase conditions were only simulated when implementing ACC or D $10 \times 0.5$ in case 3 . Therefore, to simulate a consistent cloud layer over the ocean in case $3,0.54 \mathrm{~L}^{-1}($ ACC $)<N_{\text {ice }(\text { CTT })}<1.04 \mathrm{~L}^{-1}$ $(\mathrm{D} 10 \times 0.5)$ is required.

From these three cases, it is clear that small differences in the predicted $N_{\text {ice }}$ can produce significant microphysical impacts on the modelled clouds. The best prediction of $N_{\text {ice }}$ for each case is different. Case 2 requires the least $N_{\text {ice }}$ due to the comparatively warmer CTT $\left(-12.7^{\circ} \mathrm{C}\right.$, Table 1$)$, whereas cases 1 and 3 - with similar CTTs (approximately $-20{ }^{\circ} \mathrm{C}$ ) - require $N_{\text {ice }}$ over a similar range (approximately 0.5 to $1.3 \mathrm{~L}^{-1}$ ) to produce a sustained, mixed-phase cloud layer with $N_{\text {isg }}$ and $Q_{\text {liq }}$ in approximate agreement with in situ observations. These limitations are based on the parameterisations chosen in this study $(\mathrm{C} 86, \mathrm{D} 10, \mathrm{ACC}, \mathrm{D} 10 \times 0.1$, and $\mathrm{D} 10 \times 10$ ); therefore, further work should be conducted to test other relationships and constrain the identified limitations in each case. Nevertheless, these concentrations compare well with springtime INP measurements made at the Alert station (Canadian Arctic, Mason et al., 2016), where mean INP number concentrations of $0.05,0.2$ and $1 \mathrm{~L}^{-1}$ were measured at $-15,-20$, and $-25^{\circ} \mathrm{C}$ respectively. Additionally, these results are in accordance with Ovchinnikov et al. (2011), whose modelled springtime Arctic MPS glaciated when an ice number concentration of $2 \mathrm{~L}^{-1}$ was imposed, whilst $0.5 \mathrm{~L}^{-1}$ produced mixed-phase conditions with both consistent LWP and IWPs attained after $\sim 3.5 \mathrm{~h}$. However, given these are idealised simulations (with constant SW radiation and no INP depletion), the ability of the model to simulate realistic conditions should be inferred with caution. Results from this study can simply conclude that modelled microphysics is sensitive to ice number concentrations, surface fluxes, and BL humidity (see Supplement), and that small increases in the modelled ice crystal number concentration can cause persistent mixed-phase clouds to glaciate.

\section{Conclusions}

In this study, we have used large eddy simulations to investigate the microphysical sensitivity of Arctic mixed-phase clouds to primary ice number concentrations and surface conditions. The Large Eddy Model (LEM, UK Met Office, Gray et al., 2001) was used to simulate cloud structure and evolution over the sea ice, marginal ice zone (MIZ), and ocean. Aircraft observations of cloud microphysics from the 
Aerosol-Cloud Coupling and Climate Interactions in the Arctic (ACCACIA) campaign were used as a guide to indicate which simulations gave the most realistic microphysical representation. We used two primary ice nucleation parameterisations (Cooper, 1986; DeMott et al., 2010, abbreviated to C86 and D10 respectively): one derived from ACCACIA observations (ACC, Eq. 3) and an upper and lower sensitivity test $(\mathrm{D} 10 \times 10$ and $\mathrm{D} 10 \times 0.1)$ to produce ice crystal number concentrations within the modelled clouds.

Three main sensitivities arise from the three considered cases.

- C86 cannot reproduce the sea ice cloud (case 1) under the conditions commonly used in the Weather Research and Forecasting (WRF) model with the Morrison et al. (2005) microphysics scheme (Fig. 5). However, these criteria do allow for a mixed-phase layer to form in cases 2 and 3, when the ocean provides strong sensible heat fluxes to the BL. This result demonstrates that deposition ice nucleation is not wholly representative of ice nucleation in the Arctic springtime clouds observed during the ACCACIA campaign. Ice nucleation in water-saturated conditions must be implemented to create a mixed-phase cloud layer in our three considered cases (Figs. 6, 9, and 10).

- Warm supercooled mixed-phase clouds over the MIZ (case 2) can be modelled to reasonable accuracy by using the C86 and D10 parameterisations (Fig. 9b, c). Temperatures modelled in this case are lower than observed, leading to a much greater peak $N_{\text {isg }}$ when using these parameterisations $\left(1.09\right.$ and $1.03 \mathrm{~L}^{-1}$ respectively) than would be expected from their predictions $\left(0.23\right.$ and $0.34 \mathrm{~L}^{-1}$ respectively, Table 1$)$ at the observed CTT $\left(-12.7^{\circ} \mathrm{C}\right.$, Fig. 1, Table 1). Therefore we suggest that, if the modelled temperature in case 2 was in better agreement with our observations, C86 and D10 would perform the best out of those parameterisations considered. However, both C86 and D10 overpredict the ice number concentrations at the colder temperatures modelled in cases 1 and 3 (approximately $-20^{\circ} \mathrm{C}$ ). ACC is modulated to have a weakened temperaturedependence, and it allows for persistent, mixed-phase cloud layers to be modelled in all three cases.

- Results shown here illustrate that microphysical structure of MPS is particularly sensitive to the modelled ice crystal number concentration when simulating clouds over an ocean surface. With marginally too much ice (e.g. $2.43 \mathrm{~L}^{-1}$, C86, Table 1), cloud glaciation occurs. Slightly less ice $\left(2.07 \mathrm{~L}^{-1}\right.$, D10, Table 1) allows for persistent mixed-phase conditions for some time (approximately 24h); however, convective cells form with heightened number concentrations of snow particles, which may promote cloud break-up. Conversely, too much liquid and very few ice crystals $\left(0.21 \mathrm{~L}^{-1}\right.$,
D10 $\times 0.1$, Table 1) may also promote cloud break-up via the development of large liquid (rain) particles. Case 3 simulations show that there is a "sweet spot" for simulating ice in ocean-based single-layer Arctic MPS (attained by ACC and D $10 \times 0.5$ ), where the number concentration of ice is low enough to sustain a reasonable $Q_{\text {liq }}$ through vertical motions and high enough to suppress the liquid phase and restrict efficient collisioncoalescence and rain formation. In this narrow limit, the influence of the WBF mechanism is depleted. The fact that this "sweet spot" can be attained by halving the D10 prediction of INP number concentration - yet it is overshot with $\mathrm{D} 10 \times 0.1$ - illustrates just how sensitive the cloud structure is to the ice phase. Therefore, we suggest that the method of parameterising the primary ice number concentration in bulk microphysical models is very important, as small differences in the predicted ice concentration can have substantial effects on the microphysical structure and lifetime of Arctic MPS.

These idealised simulations assume an infinite source of INPs to the modelled clouds; INPs are not depleted by activation or precipitation. An infinite source of INPs is likely unrepresentative of the Arctic environment (Pinto, 1998), as there are few in situ sources of INPs (e.g. mineral dusts, Murray et al., 2012). Although Young et al. (2016b) identified mineral dusts during all flights of the ACCACIA campaign, further work should include prognosing INPs in such simulations to investigate how their depletion could affect the microphysical structure of these clouds. Several studies have previously identified INP depletion as an important process to represent when modelling Arctic MPS (Harrington et al., 1999; Harrington and Olsson, 2001, amongst others).

Additionally, the Morrison et al. (2005) microphysics scheme has been used for its detailed representation of microphysical interactions, such as ice aggregation and growth, but it can be utilised further to represent aerosol particle properties. Size distributions can be prescribed; therefore, the D10 parameterisation could be developed to give a spatially dependent INP prediction based on aerosol particle observations, likely leading to a more comprehensive treatment of INP variability throughout the domain.

Data availability. Processed data from the ACCACIA campaign are archived on the NCAS British Atmospheric Data Centre (http:// catalogue.ceda.ac.uk/uuid/88f95b1d52804b27882fbb798b116d3a). LEM model runs are archived at the University of Manchester and are available on request.

The Supplement related to this article is available online at doi:10.5194/acp-17-4209-2017-supplement. 
Competing interests. The authors declare that they have no conflict of interest.

Acknowledgements. This work was funded as part of the ACCACIA campaign (grant NE/I028696/1) by the National Environment Research Council (NERC). Gillian Young was supported by a NERC PhD studentship. We would like to thank A. Hill and B. Shipway for advising on the microphysics scheme, A. Wellpott for advising on the dropsonde dry biases, and K. Bower, M. Gallagher, and J. Crosier for helpful discussions throughout the duration of the study. Airborne data were obtained using the BAe-146-301 Atmospheric Research Aircraft [ARA] flown by Directflight Ltd and managed by the Facility for Airborne Atmospheric Measurements [FAAM], which is a joint entity of the Natural Environment Research Council [NERC] and the Met Office. Sea ice data were obtained from the National Snow and Ice Data Centre (NSIDC).

Edited by: L. M. Russell

Reviewed by: R. Jackson and two anonymous referees

\section{References}

ACIA: Arctic Climate Impact Assessment, Cambridge University Press, 990-1020, 2005.

Bigg, E. K.: The formation of atmospheric ice crystals by the freezing of droplets, Q. J. Roy. Meteorol. Soc., 79, 510-519, doi:10.1002/qj.49707934207, 1953.

Bigg, E. K. and Leck, C.: Cloud-active particles over the central Arctic Ocean, J. Geophys. Res., 106, 32155, doi:10.1029/1999JD901152, 2001.

Boucher, O., Randall, D., Artaxo, P., Bretherton, C., Feingold, G., Forster, P., Kerminen, V. M., Kondo, Y., Liao, H., Lohmann, U., Rasch, P., Satheesh, S. K., Sherwood, S., Stevens, B., and Zhang, X. Y.: Clouds and Aerosols, in: Climate Change 2013: The Physical Science Basis, Contribution of Working Group I to the Fifth Assessment Report of the Intergovernmental Panel on Climate Change, edited by: Stocker, T. F., Qin, D., Plattner, G. K., Tignor, M., Allen, S. K., Boschung, J., Nauels, A., Xia, Y., Bex, V., and Midgley, P. M., Cambridge University Press, Cambridge, United Kingdom and New York, NY, USA, doi:10.1017/CBO9781107415324.016, 2013.

Cooper, W. A.: Ice Initiation in Natural Clouds, Meteorol. Monogr., 21, 29-32, doi:10.1175/0065-9401-21.43.29, 1986.

Courant, R., Friedrichs, K., and Lewy, H.: On the Partial Difference Equations of Mathematical Physics, IBM J. Res. Dev., 11, 215234, doi:10.1147/rd.112.0215, 1967.

Crosier, J., Bower, K. N., Choularton, T. W., Westbrook, C. D., Connolly, P. J., Cui, Z. Q., Crawford, I. P., Capes, G. L., Coe, H., Dorsey, J. R., Williams, P. I., Illingworth, A. J., Gallagher, M. W., and Blyth, A. M.: Observations of ice multiplication in a weakly convective cell embedded in supercooled mid-level stratus, Atmos. Chem. Phys., 11, 257-273, doi:10.5194/acp-11-257-2011, 2011.

Crosier, J., Choularton, T. W., Westbrook, C. D., Blyth, A. M., Bower, K. N., Connolly, P. J., Dearden, C., Gallagher, M. W., Cui, Z., and Nicol, J. C.: Microphysical properties of cold frontal rainbands, Q. J. Roy. Meteorol. Soc., 140, 1257-1268, doi:10.1002/qj.2206, 2014.

Curry, J. A., Rossow, W. B., Randall, D., and Schramm, J. L.: Overview of Arctic Cloud and Radiation Characteristics., J. Climate, 9, 1731-1764, doi:10.1175/15200442(1996)009<1731:OOACAR>2.0.CO;2, 1996.

de Boer, G., Hashino, T., and Tripoli, G. J.: Ice nucleation through immersion freezing in mixed-phase stratiform clouds: Theory and numerical simulations, Atmos. Res., 96, 315-324, doi:10.1016/j.atmosres.2009.09.012, 2010.

de Boer, G., Morrison, H., Shupe, M. D., and Hildner, R.: Evidence of liquid dependent ice nucleation in high-latitude stratiform clouds from surface remote sensors, Geophys. Res. Lett., 38, L01803, doi:10.1029/2010GL046016, 2011.

de Boer, G., Shupe, M. D., Caldwell, P. M., Bauer, S. E., Persson, O., Boyle, J. S., Kelley, M., Klein, S. A., and Tjernström, M.: Near-surface meteorology during the Arctic Summer Cloud Ocean Study (ASCOS): evaluation of reanalyses and global climate models, Atmos. Chem. Phys., 14, 427-445, doi:10.5194/acp-14-427-2014, 2014.

DeMott, P. J., Prenni, A. J., Liu, X., Kreidenweis, S. M., Petters, M. D., Twohy, C. H., Richardson, M. S., Eidhammer, T., and Rogers, D. C.: Predicting global atmospheric ice nuclei distributions and their impacts on climate, P. Natl. Acad. Sci. USA, 107, 11217-11222, doi:10.1073/pnas.0910818107, 2010.

Edwards, J. M. and Slingo, A.: Studies with a flexible new radiation code. I: Choosing a configuration for a largescale model, Q. J. Roy. Meteorol. Soc., 122, 689-719, doi:10.1002/qj.49712253107, 1996.

Fan, J., Wang, Y., Rosenfeld, D., and Liu, X.: Review of AerosolCloud Interactions: Mechanisms, Significance, and Challenges, J. Atmos. Sci., 73, 4221-4252, doi:10.1175/JAS-D-16-0037.1, 2016.

Gray, M. E. B., Petch, J. C., Derbyshire, S. H., Brown, A. R., Lock, A. P., Swann, H. A., and Brown, P. R. A.: Version 2.3 of the Met Office Large Eddy Model: Part II, Scientific Documentation, Tech. rep., 2001.

Hallett, J. and Mossop, S. C.: Production of Secondary Ice Particles during the Riming Process, Nature, 249, 26-28, doi:10.1038/249026a0, 1974.

Harrington, J. Y. and Olsson, P. Q.: On the potential influence of ice nuclei on surface-forced marine stratocumulus cloud dynamics, J. Geophys. Res.-Atmos., 106, 27473-27484, doi:10.1029/2000JD000236, 2001.

Harrington, J. Y., Reisin, T., Cotton, W. R., and Kreidenweis, S. M.: Cloud resolving simulations of Arctic stratus, Part II: Transitionseason clouds, Atmos. Res., 51, 45-75, doi:10.1016/S01698095(98)00098-2, 1999.

Hartmann, J., Kottmeier, C., and Raasch, S.: Roll Vortices and Boundary-Layer Development during a Cold Air Outbreak, Bound.-Lay. Meteorol., 84, 45-65, doi:10.1023/A:1000392931768, 1997.

Hobbs, P. V. and Rangno, A. L.: Microstructures of low and middlelevel clouds over the Beaufort Sea, Q. J. Roy. Meteorol. Soc., 124, 2035-2071, doi:10.1002/qj.49712455012, 1998.

Jackson, R. C., McFarquhar, G. M., Korolev, A. V., Earle, M. E., Liu, P. S. K., Lawson, R. P., Brooks, S., Wolde, M., Laskin, A., and Freer, M.: The dependence of ice microphysics on aerosol concentration in arctic mixed-phase stratus clouds during IS- 
DAC and M-PACE, J. Geophys. Res.-Atmos., 117, D15207, doi:10.1029/2012JD017668, 2012.

Klein, S. A., McCoy, R. B., Morrison, H., Ackerman, A. S., Avramov, A., Boer, G. d., Chen, M., Cole, J. N. S., Del Genio, A. D., Falk, M., Foster, M. J., Fridlind, A., Golaz, J.-C., Hashino, T., Harrington, J. Y., Hoose, C., Khairoutdinov, M. F., Larson, V. E., Liu, X., Luo, Y., McFarquhar, G. M., Menon, S., Neggers, R. A. J., Park, S., Poellot, M. R., Schmidt, J. M., Sednev, I., Shipway, B. J., Shupe, M. D., Spangenberg, D. A., Sud, Y. C., Turner, D. D., Veron, D. E., Salzen, K. v., Walker, G. K., Wang, Z., Wolf, A. B., Xie, S., Xu, K.-M., Yang, F., and Zhang, G.: Intercomparison of model simulations of mixed-phase clouds observed during the ARM Mixed-Phase Arctic Cloud Experiment, I: single-layer cloud, Q. J. Roy. Meteorol. Soc., 135, 979-1002, doi:10.1002/qj.416, 2009.

Korolev, A. and Isaac, G.: Phase transformation of mixedphase clouds, Q. J. Roy. Meteorol. Soc., 129, 19-38, doi:10.1256/qj.01.203, 2003.

Lance, S., Brock, C. A., Rogers, D., and Gordon, J. A.: Water droplet calibration of the Cloud Droplet Probe (CDP) and inflight performance in liquid, ice and mixed-phase clouds during ARCPAC, Atmos. Meas. Tech., 3, 1683-1706, doi:10.5194/amt3-1683-2010, 2010.

Lawson, R. P., O'Connor, D., Zmarzly, P., Weaver, K., Baker, B., Mo, Q., and Jonsson, H.: The 2D-S (Stereo) Probe: Design and Preliminary Tests of a New Airborne, High-Speed, HighResolution Particle Imaging Probe, J. Atmos. Ocean. Tech., 23, 1462, doi:10.1175/JTECH1927.1, 2006.

Lloyd, G., Choularton, T. W., Bower, K. N., Crosier, J., Jones, H., Dorsey, J. R., Gallagher, M. W., Connolly, P., Kirchgaessner, A. C. R., and Lachlan-Cope, T.: Observations and comparisons of cloud microphysical properties in spring and summertime Arctic stratocumulus clouds during the ACCACIA campaign, Atmos. Chem. Phys., 15, 3719-3737, doi:10.5194/acp-15-37192015, 2015.

Mason, B. J.: Growth Habits and Growth Rates of Snow Crystals, Proc. R. Soc. Lon. Ser.-A, 441, 3-16, doi:10.1098/rspa.1993.0045, 1993.

Mason, R. H., Si, M., Chou, C., Irish, V. E., Dickie, R., Elizondo, P., Wong, R., Brintnell, M., Elsasser, M., Lassar, W. M., Pierce, K. M., Leaitch, W. R., MacDonald, A. M., Platt, A., Toom-Sauntry, D., Sarda-Estève, R., Schiller, C. L., Suski, K. J., Hill, T. C. J., Abbatt, J. P. D., Huffman, J. A., DeMott, P. J., and Bertram, A. K.: Size-resolved measurements of ice-nucleating particles at six locations in North America and one in Europe, Atmos. Chem. Phys., 16, 1637-1651, doi:10.5194/acp-16-1637-2016, 2016.

McFarquhar, G. M., Ghan, S., Verlinde, J., Korolev, A., Strapp, J. W., Schmid, B., Tomlinson, J. M., Wolde, M., Brooks, S. D., Cziczo, D., Dubey, M. K., Fan, J., Flynn, C., Gultepe, I., Hubbe, J., Gilles, M. K., Laskin, A., Lawson, P., Leaitch, W. R., Liu, P., Liu, X., Lubin, D., Mazzoleni, C., MacDonald, A.-M., Moffet, R. C., Morrison, H., Ovchinnikov, M., Shupe, M. D., Turner, D. D., Xie, S., Zelenyuk, A., Bae, K., Freer, M., and Glen, A.: Indirect and Semi-direct Aerosol Campaign: The Impact of Arctic Aerosols on Clouds, B. Am. Meteorol. Soc., 92, 183-201, doi:10.1175/2010BAMS2935.1, 2011.

Meyers, M. P., Demott, P. J., and Cotton, W. R.: New Primary Ice-Nucleation Parameterizations in an Explicit Cloud
Model, J. Appl. Meteorol., 31, 708-721, doi:10.1175/15200450(1992)031<0708:NPINPI>2.0.CO;2, 1992.

Morrison, H., Curry, J. A., and Khvorostyanov, V. I.: A New Double-Moment Microphysics Parameterization for Application in Cloud and Climate Models, Part I: Description, J. Atmos. Sci., 62, 1665-1677, doi:10.1175/JAS3446.1, 2005.

Morrison, H., Pinto, J. O., Curry, J. A., and McFarquhar, G. M.: Sensitivity of modeled arctic mixed-phase stratocumulus to cloud condensation and ice nuclei over regionally varying surface conditions, J. Geophys. Res.-Atmos., 113, D05203, doi:10.1029/2007JD008729, 2008.

Morrison, H., McCoy, R. B., Klein, S. A., Xie, S., Luo, Y., Avramov, A., Chen, M., Cole, J. N. S., Falk, M., Foster, M. J., Del Genio, A. D., Harrington, J. Y., Hoose, C., Khairoutdinov, M. F., Larson, V. E., Liu, X., McFarquhar, G. M., Poellot, M. R., von Salzen, K., Shipway, B. J., Shupe, M. D., Sud, Y. C., Turner, D. D., Veron, D. E., Walker, G. K., Wang, Z., Wolf, A. B., Xu, K.-M., Yang, F., and Zhang, G.: Intercomparison of model simulations of mixed-phase clouds observed during the ARM MixedPhase Arctic Cloud Experiment, II: Multilayer cloud, Q. J. Roy. Meteorol. Soc., 135, 1003-1019, doi:10.1002/qj.415, 2009.

Morrison, H., Zuidema, P., Ackerman, A. S., Avramov, A., de Boer, G., Fan, J., Fridlind, A. M., Hashino, T., Harrington, J. Y., Luo, Y., Ovchinnikov, M., and Shipway, B.: Intercomparison of cloud model simulations of Arctic mixed-phase boundary layer clouds observed during SHEBA/FIRE-ACE, Journal of Advances in Modeling Earth Systems, 3, M06003, doi:10.1029/2011MS000066, 2011.

Morrison, H., de Boer, G., Feingold, G., Harrington, J., Shupe, M. D., and Sulia, K.: Resilience of persistent Arctic mixed-phase clouds, Nat. Geosci., 5, 11-17, doi:10.1038/ngeo1332, 2012.

Murray, B. J., O’Sullivan, D., Atkinson, J. D., and Webb, M. E.: Ice nucleation by particles immersed in supercooled cloud droplets, Chem. Soc. Rev., 41, 6519-6554, doi:10.1039/c2cs35200a, 2012.

Ovchinnikov, M., Korolev, A., and Fan, J.: Effects of ice number concentration on dynamics of a shallow mixed-phase stratiform cloud, J. Geophys. Res.-Atmos., 116, D00T06, doi:10.1029/2011JD015888, 2011.

Pinto, J. O.: Autumnal Mixed-Phase Cloudy Boundary Layers in the Arctic, J. Atmos. Sci., 55, 2016-2038, doi:10.1175/15200469(1998)055<2016:AMPCBL>2.0.CO;2, 1998.

Prenni, A. J., Harrington, J. Y., Tjernström, M., Demott, P. J., Avramov, A., Long, C. N., Kreidenweis, S. M., Olsson, P. Q., and Verlinde, J.: Can Ice-Nucleating Aerosols Affect Arctic Seasonal Climate?, B. Am. Meteorol. Soc., 88, 541-550, doi:10.1175/BAMS-88-4-541, 2007.

Pruppacher, H. R. and Klett, J. D.: Microphysics of Clouds and Precipitation, Kluwer Academic Publishers, 1997.

Rangno, A. L. and Hobbs, P. V.: Ice particles in stratiform clouds in the Arctic and possible mechanisms for the production of high ice concentrations, J. Geophys. Res.-Atmos., 106, 15065-15075, doi:10.1029/2000JD900286, 2001.

Rosenberg, P. D., Dean, A. R., Williams, P. I., Dorsey, J. R., Minikin, A., Pickering, M. A., and Petzold, A.: Particle sizing calibration with refractive index correction for light scattering optical particle counters and impacts upon PCASP and CDP data collected during the Fennec campaign, Atmos. Meas. Tech., 5, 1147-1163, doi:10.5194/amt-5-1147-2012, 2012. 
Serreze, M. C. and Barry, R. G.: Processes and impacts of Arctic amplification: A research synthesis, Global Planet. Change, 77, 85-96, doi:10.1016/j.gloplacha.2011.03.004, 2011.

Shupe, M. D., Matrosov, S. Y., and Uttal, T.: Arctic MixedPhase Cloud Properties Derived from Surface-Based Sensors at SHEBA, J. Atmos. Sci., 63, 697-711, doi:10.1175/JAS3659.1, 2006.

Shupe, M. D., Daniel, J. S., de Boer, G., Eloranta, E. W., Kollias, P., Long, C. N., Luke, E. P., Turner, D. D., and Verlinde, J.: A Focus On Mixed-Phase Clouds, B. Am. Meteorol. Soc., 89, 1549-1562, doi:10.1175/2008BAMS2378.1, 2008a.

Shupe, M. D., Kollias, P., Persson, P. O. G., and McFarquhar, G. M.: Vertical Motions in Arctic Mixed-Phase Stratiform Clouds, J. Atmos. Sci., 65, 1304-1322, doi:10.1175/2007JAS2479.1, 2008b.

Shupe, M. D., Walden, V. P., Eloranta, E., Uttal, T., Campbell, J. R., Starkweather, S. M., and Shiobara, M.: Clouds at Arctic Atmospheric Observatories, Part I: Occurrence and Macrophysical Properties, J. Appl. Meteorol. Clim., 50, 626-644, doi:10.1175/2010JAMC2467.1, 2011.

Sotiropoulou, G., Sedlar, J., Tjernström, M., Shupe, M. D., Brooks, I. M., and Persson, P. O. G.: The thermodynamic structure of summer Arctic stratocumulus and the dynamic coupling to the surface, Atmos. Chem. Phys., 14, 12573-12592, doi:10.5194/acp-14-12573-2014, 2014.

Stocker, T., Qin, D., Plattner, G.-K., Alexander, L., Allen, S., Bindoff, N., Bréon, F.-M., Church, J., Cubasch, U., Emori, S., Forster, P., Friedlingstein, P., Gillett, N., Gregory, J., Hartmann, D., Jansen, E., Kirtman, B., Knutti, R., Krishna Kumar, K., Lemke, P., Marotzke, J., Masson-Delmotte, V., Meehl, G., Mokhov, I., Piao, S., Ramaswamy, V., Randall, D., Rhein, M., Rojas, M., Sabine, C., Shindell, D., Talley, L., Vaughan, D., and Xie, S.-P.: Technical Summary, in: Climate Change 2013: The Physical Science Basis, Contribution of Working Group I to the Fifth Assessment Report of the Intergovernmental Panel on Climate Change, edited by: Stocker, T. F., Qin, D., Plattner, G.-K., Tignor, M., Allen, S. K., Boschung, J., Nauels, A., Xia, Y., Bex, V., and Midgley, P. M., Cambridge University Press, Cambridge, United Kingdom and New York, NY, USA, doi:10.1017/CBO9781107415324.005, 2013.

Taylor, J. W., Choularton, T. W., Blyth, A. M., Liu, Z., Bower, K. N., Crosier, J., Gallagher, M. W., Williams, P. I., Dorsey, J. R., Flynn, M. J., Bennett, L. J., Huang, Y., French, J., Korolev, A., and Brown, P. R. A.: Observations of cloud microphysics and ice formation during COPE, Atmos. Chem. Phys., 16, 799-826, doi:10.5194/acp-16-799-2016, 2016.
Tjernström, M., Sedlar, J., and Shupe, M. D.: How Well Do Regional Climate Models Reproduce Radiation and Clouds in the Arctic? An Evaluation of ARCMIP Simulations, J. Appl. Meteorol. Clim., 47, 2405-2422, doi:10.1175/2008JAMC1845.1, 2008.

Verlinde, J., Harrington, J. Y., McFarquhar, G. M., Yannuzzi, V. T., Avramov, A., Greenberg, S., Johnson, N., Zhang, G., Poellot, M. R., Mather, J. H., Turner, D. D., Eloranta, E. W., Zak, B. D., Prenni, A. J., Daniel, J. S., Kok, G. L., Tobin, D. C., Holz, R., Sassen, K., Spangenberg, D., Minnis, P., Tooman, T. P., Ivey, M. D., Richardson, S. J., Bahrmann, C. P., Shupe, M., Demott, P. J., Heymsfield, A. J., and Schofield, R.: The Mixed-Phase Arctic Cloud Experiment, B. Am. Meteorol. Soc., 88, 205-221, doi:10.1175/BAMS-88-2-205, 2007.

Vihma, T., Pirazzini, R., Fer, I., Renfrew, I. A., Sedlar, J., Tjernström, M., Lüpkes, C., Nygård, T., Notz, D., Weiss, J., Marsan, D., Cheng, B., Birnbaum, G., Gerland, S., Chechin, D., and Gascard, J. C.: Advances in understanding and parameterization of small-scale physical processes in the marine Arctic climate system: a review, Atmos. Chem. Phys., 14, 9403-9450, doi:10.5194/acp-14-9403-2014, 2014.

Young, G., Jones, H. M., Choularton, T. W., Crosier, J., Bower, K. N., Gallagher, M. W., Davies, R. S., Renfrew, I. A., Elvidge, A. D., Darbyshire, E., Marenco, F., Brown, P. R. A., Ricketts, H. M. A., Connolly, P. J., Lloyd, G., Williams, P. I., Allan, J. D., Taylor, J. W., Liu, D., and Flynn, M. J.: Observed microphysical changes in Arctic mixed-phase clouds when transitioning from sea ice to open ocean, Atmos. Chem. Phys., 16, 13945-13967, doi:10.5194/acp-16-13945-2016, 2016a.

Young, G., Jones, H. M., Darbyshire, E., Baustian, K. J., McQuaid, J. B., Bower, K. N., Connolly, P. J., Gallagher, M. W., and Choularton, T. W.: Size-segregated compositional analysis of aerosol particles collected in the European Arctic during the ACCACIA campaign, Atmos. Chem. Phys., 16, 4063-4079, doi:10.5194/acp-16-4063-2016, 2016 b.

Young, K. C.: The Role of Contact Nucleation in Ice Phase Initiation in Clouds, J. Atmos. Sci., 31, 768-776, doi:10.1175/15200469(1974)031<0768:TROCNI>2.0.CO;2, 1974. 